\title{
Bir Simülasyon Olarak Eğitim ve Eğitim Programları
}

\section{Education and Curriculum as a Simulation}

\section{Volkan Duran ${ }^{1}$, Güliz KaymakcI $^{2}$, Ahmet Ünal ${ }^{3}$}

\section{Anahtar Kelimeler \\ Baudrillard \\ Simülasyon kuramı \\ Program geliştirme}

\section{Keywords}

Baudrillard

Simulation theory

Curriculum development

Başvuru Tarihi/Received

18.09.2019

Kabul Tarihi /Accepted

07.10.2019

\section{Öz}

Günümüzdeki en etkili medya kuramcılarından birisi olan Fransız post modern yazar Jean Baudrillard modern kitle iletişim araçlarının etkisinin diğer teknolojilerin etkisinden daha farklı ve derin olduğunu vurgulamıştır. Baudrillard'a göre, kitle iletişiminin özellikle de televizyon gibi elektronik medyanın gelişi tam da yaşamlarımızın niteliğini değiştirmiştir. Televizyon bize yalnızca dünyayı göstermez, giderek içinde yaşadığımız dünyanın aslında ne olduğunu belirler. Benzer şekilde, Fransız düşünür Jean Baudrillard'ın geliştirdiği "Simülasyon Kuramı" bu olguları kültürel simgesel sistemi anlamada simülakr kavramıyla açıklamıştır. Buna göre, gerçekliğin "gibiliği" ya da gözükmesi, sosyal yaşamı düzenlemektedir. Simülakr, toplumun kendisini, çevresini nasıl anladığını belirleyen kategorilerle birlikte bir gerçeklik ilkesi sunmaktadır. Simülakrlar statükoyu sürdürmek ve yeniden üretmek anlamında kurumsal uygulamalar düzenlemektedir. Simülakr tarihsel olarak yavaş yavaş gelişir. Baudrillard, "Simulacra and Simulation" adlı eserinde eğitimin olmadığını sadece ileri kapitalizmde doğabilecek eşitsizlikleri maskeleyen bir eğitim simülasyonu olduğunu vurgulamıștır. Bu bağlamda "eğitim programları bir simülakr olarak ele alınabilir mi?" sorusu bu çalışmanın temel amacını oluşturmaktadır. Araştırmada önce Baudrillard felsefesi incelenecektir. İkinci aşamada ise eğitimde program geliştirmede ihtiyaç analizi açısından Baudrillard'ın görüşleri ele alınacaktır. Üçüncü aşamada ise program geliştirmenin ekonomik, sosyal ve felsefi temelleri açısından Baudrillard'ın görüşleri ele alınacaktır. Son olarak ise program geliştirme modelleri açısından Baudrillard'ın görüşleri incelenecektir. Çalışma sonuçları literatürle tartışıldıktan sonra konuyla ilgili öneriler belirtilmiştir.

\section{Abstract}

One of the most influential media theorists, the French postmodernist Jean Baudrillard, emphasized that the impact of modern mass media is significantly different and has deeper effects than the impact of other technologies. According to him, the advent of mass media, especially electronic media such as television, has changed the quality of our lives. Television does not only show us the world, but it determines what the world we live in is actually what it is (Giddens, 2012). Similarly, the Simulation Theory developed by the French thinker Jean Baudrillard explained these facts with the concept of the concept of simulacrum to understand the cultural symbolic system. According to this, the pretense of reality regulates social life. Simulacrum presents a principle of reality with the categories that determine how society understands itself and its environment. Simulacrums organize institutional practices in terms of maintaining and reproducing the status quo. Simulacrum develops slowly (Aydoğan, Yaylacı, 2005). Baudrillard argues that a simulacrum is not a copy of the real but becomes truth in its own right. In this context Baudrillard emphasized that there is no education, but there is a training simulation that masks inequalities that can only arise in advanced capitalism. In this context, the question whether the curriculums be considered as a simulacrum is the main purpose of this study. In the study, Baudrillard philosophy will be examined first. In the second stage, Baudrillard's views will be discussed in terms of needs analysis in curriculum development. In the third stage, Baudrillard's views will be discussed in terms of the economic, social and philosophical foundations of program development. Finally, Baudrillard's views will be examined in terms of program development models.

\footnotetext{
${ }^{1}$ Iğdır Üniversitesi, Fen Edebiyat Fakültesi, Psikoloji, Iğdır, TÜRKiYE; https://orcid.org/ 0000-0003-0692-0265

${ }^{2}$ Muğla Sıtkı Koçman Üniversitesi, Eğitim Fakültesi, Matematik ve Fen Bilimleri Eğitimi, Muğla, TÜRKiYE; https://orcid.org/ 0000-0002-3428-5214

${ }^{3}$ Sorumlu Yazar: Kastamonu Üniversitesi, Eğitim Fakültesi, Temel Eğitim Bölümü, Kastamonu, TÜRKiYE; https://orcid.org/ 0000-0001-8617-6602
} 


\section{Extended Abstract}

\section{Introduction}

One of the most influential media theorists, the French postmodernist Jean Baudrillard, emphasized that the impact of modern mass media is significantly different and has deeper effects than the impact of other technologies. According to him, the advent of mass media, especially electronic media such as television, has changed the quality of our lives. Television does not only show us the world, but it determines what the world we live in is actually what it is (Giddens, 2012). Similarly, the Simulation Theory developed by the French thinker Jean Baudrillard explained these facts with the concept of the concept of simulacrum to understand the cultural symbolic system. According to this, the pretense of reality regulates social life. Simulacrum presents a principle of reality with the categories that determine how society understands itself and its environment. Simulacrums organize institutional practices in terms of maintaining and reproducing the status quo. Simulacrum develops slowly (Aydoğan and Yaylacı, 2005). Baudrillard argues that a simulacrum is not a copy of the real, but becomes truth in its own right. In this context Baudrillard emphasized that there is no education, but there is a training simulation that masks inequalities that can only arise in advanced capitalism. Baudrillard's main argument is that in the postmodern era we can no longer distinguish between the "hyper-

real" which is the artificially recreated version of the real and the "real". This means that simulation overturns and changes the reality itself. In other words, what is called simulation does not emerge as something that conceals the truth, but rather the reality itself (Kara, 2019: 1). According to this, "knowledge emerges as the information of the disappearance of truth and reality in the most fundamental way rather than something produced as a result of an isolated objectobject relationship (Güzel, 2015: 69).

\section{Method}

In this study, one of the qualitative research methods, document analysis method was used. Records of an event or process taken by individuals or groups in different ways are defined as documents. Online archive resources are also considered as documents. According to Karasar (2008), document analysis includes pictures, films, etc., which bear traces of past phenomena. According to this, firstly the records related to the subject were collected, examined and evaluated by taking into consideration the determined criteria (Ekiz, 2009). Within the scope of the study, in the light of Baudrillard's main works, master's theses and doctoral dissertations in YÖK National Thesis Center were examined and interpreted through various Turkish articles. Especially when selecting works following criteria is taken into account:

Criterion 1- Baudrillard's name or Baudrillard's concepts of simulation and simulacr should be in the title or summary.

Criterion 2-In addition, it was taken to ensure that the contents of the work were directly related to Baudrillard's philosophy.

When analyzing the data, first of all, related comments and sentences collected by a researcher were written in an essay form. In the second stage, the essay was revised by the other two researchers in the context of the relevant literature. In the last stage, the article was reinterpreted by the first author and it was finalized with the arrangement of all three authors.

\section{Result and Discussion}

The radical questioning of Jean Baudrillard's sign, symbol and simulation concepts in our postmodern age is important for the evaluation of contemporary educational practices because education is also the part of contemporary society. Baudrillard's theory of simulation is not the conflict of the abstract and concrete; but is the battle of imitation with reality. Imitations replacing reality; it reveals the hyper-reality which is the result of the indifference of the artificial from the real (Okuyan, 2018: 3). At this point, it can be said that the production of information can be handled in parallel with the production of the image. In this context, knowledge has been produced in four stages from past to present.

The knowledge phase as a reflection of a deep reality points to this period of human history, the period before the industrial revolution that began in the 18th century. Because of the direct correlation between the chair and the symbolic significance it represents (investment in time, work and expertise), anyone who made it to the chair could quickly understand and "read" its meaning. Similarly, law, religion or philosophy, which could be considered more abstract disciplines reflected a metaphysics built on this concreteness of knowledge.

The phase of knowledge that alters and hides a deep reality is roughly the mid-18th to 19th centuries coinciding with the emergence of nationstates and the early industrial revolution after the French Revolution. At this stage, the symbolic meaning of knowledge begins to dissolve or disintegrate, and its relationship to reality becomes weaker. In this scenario, a chair is still designed and produced by a skilled craftsman however, the direct link between chair ("decisive") and investment in time, work and expertise ("specified") is sacrificed for efficiency. Although more than one chair can quickly exit the assembly line and be distributed and sold to more people, each chair produced contains only a part of the "meaning" of the firstorder protype chair.

The stage of knowledge that conceals the absence of a deep reality coincides with the rise of the industrial era, from the late 19th century to the late 20th century. At this stage, something else happens in the spread of mechanization: objects were neither initially created from their first prototypes for beauty or quality, nor for their original use but for ease of use. This can be 
examplified by the fruits and vegetables that are grown because they can be sent over long distances, rather than flavor or nutritional value. In this context, what drives consumption is not the necessity, but marketing and advertising.

The phase of knowledge which is not pure to any kind of reality, and which is pure self-simulation, returns to an entertainment space where the connection between symbolic and reality is completely solved and what we obtain enters into an infinite series of reflection. The most typical example is the examination system. Accordingly, the ratio and proportion subject in mathematics is not a knowledge that is learned in order to analyze the ratio and proportion between things in the real world, but a symbolic problem that must be solved in certain patterns. Accordingly, the most known triangle 345 is a pattern of geometry independent of the ratio and proportion. The law of multiple proportion in chemistry or torque in physics is a relationship that arises in certain problem patterns that are independent of the ratio and proportion. For this reason, the "real" the ratio and proportion is more a mathematical pattern related to fractions. This is exactly what it defines as the production of a hyper-reality (réel), which is actually more real than "the real" (Kartal, 2013: 76).

Although the rhetoric that curriculums are conducted according to needs analysis is at the forefront, how objective these needs are and how those needs are determined are open questions regarding the curriculums The most basic problem arises in the definition of the need. It should be taken into consideration that the education programs are designed according to the needs of certain social groups rather than the needs of the whole society. Thus, a curriculum makes the ideal human model based on these needs and simulation logic by creating varios centers of attraction, images and models endlessly to ensure the continuity of the system. Thus, needs now target values rather than objects, and satisfaction of needs means adopting these values first. The unconscious, automatic basic preference of the consumer is to adopt the lifestyle of a particular society in this regard (Baudrillard, 2013: 73). Curriculums are the means of achieving this also.

Suggestions for the results of this study are as follows:

- Considering Baudrillard's ideas, it should be explored and examined how simulation of information can be directed in positive ways or how risks can be turned into opportunities.

- In the context of Baudrillard's ideas, educational programs should be examined, including implicit program aspects, and the integration of technology should not be seen as a simple content update in education.

- In addition to exams that are suspicious of choosing who is truly successful because it provides objectivity, opportunities should be recognized and created for individuals to manifest themselves in other ways.

Recommendations for future studies are as follows:

- This study can be done by taking the opinions of students, teachers and academics in terms of Baudrillard's ideas.

- $\quad$ This study can be applied to a more indepth sociological research using different interview designs, for example using interview method.

- $\quad$ This study can be re-examined by comparing in terms of different texts and views of different philosophers. 
Giriş

Tarih boyunca hakikat, gerçek ve doğru olan üzerine birçok tartışma yapılmış ve bu tartışmalar doğrultusunda birçok felsefe ve bilimsel teori ortaya atılmıştır. Bununla beraber, geçtiğimiz son iki yüzyıl gelişen iletişim araçlarıyla hakikate bakışta bambaşka bir bakış açısı sunmuştur. Artık orada ve burada ayrımı kalkmış, zaman ve mekân arasındaki ilişki nedensellik anlayışının dışına çıkmıştır. Bu bağlamda, özellikle sanal olana, hiper-gerçekliğe ilişkin görüşleriyle Jean Baudrillard (1929-2007) öne çıkan bir filozof, sosyolog ve kültür teorisyeni olarak ön plana çıkmıştır. Kuramsal bir terörist olarak nitelenen Baudrillard, öne sürdüğü fikirleriyle Batı'nın evrensellik adına yapmış olduğu bütün eylem ve söylemlerin boş olduğuna vurgu yapmış ve Batı medeniyetinin mutlak anlamda çökeceğini öngörmüştür (Çimen, 2018: 2).

Jean Baudrillard'ın tanınmasını sağlayan en ünlü ve muhtemelen en etkili eseri, 1981 yılında yazılmış, gerçeklik ile sembolik rekreasyonlar arasındaki ilişkiyi ele aldığı Simülakrlar ve Simülasyon kitabıdır. Bu eserde O, günümüz politik ve ideolojik hareketlerine dönük radikal bir eleştiri ortaya koymuştur (Kara, 2019: 1). Baudrillard eleştirilerinde medyanın ticarileşmesi sonuç, imge ve sanat tüketimine verilen önemine ve gelişen teknolojilerin günümüze olan etkisine odaklanmıştır (Dursun, 2018: 1). Baudrillard temel olarak günümüz dünyasında gerçekliğin ortadan kaybolma aşamasına nasıl geldiğini ve "gerçek olandan daha gerçek" modellerle değiştirildiğini incelemiştir. Bu mevcut durum teşhisini çevreleyen temel fikir hiper-gerçeklik dediği şeydir (Mendoza, 2010: 46). "Simulacra ve Simülasyon" da Baudrillard, sadece Simülakrlar ve simülasyonun mevcut olduğu bir dünyada neler olduğunu sorgulamıştır (Dursun, 2018: 5). Baudrillard'ın temel argümanı, postmodern çağda, artık gerçek olanın yapay olarak yeniden yaratılmış bir versiyonu olan "hiper-gerçek" ile "gerçek" olanları birbirinden ayırt edemeyeceğimiz şeklindedir. Bu simülasyon'un gerçeği devirmesi ve değiştirmesi anlamına gelmektedir. Başka bir deyişle simülasyon denilen şey, gerçeği gizleyen bir şey olarak ortaya çıkmamakta tam tersine gerçeğin kendisi olmaktadır (Kara, 2019: 1). Buna göre "bilgi" yalıtık bir öznenesne ilişkisi sonucunda üretilen bir şeyden çok en temelde hakikatin ve "gerçekliğin" yok oluşunu da haber veren bir şey olarak ortaya çıkmaktadır (Güzel, 2015: 69). Bu bağlamda Baudrillard, hakikatin değişiminin sebebi olarak 'sanal'ı ortaya koymuştur. Burada sanal televizyon ve internet gibi yeni tür iletişim araçlarını ifadeeder. Artık bireyler, bu aygıtların yarattığı evrende birer "kitle" gerçeği haline gelmiş ve televizyon, reklam, imaj ve imgeler vasıtasıyla sanal olana inandırılmış ve kendi gerçekliklerini yitirmişlerdir (Okuyan, 2018: 50). Bu sanal algıların gerçek algıların yerini almaya başlaması anlamına gelmektedir (Dursun, 2018: 1). Baudrillard, 1970'li yılların ortalarındaki süreçte modern öncesi sembolik toplumlarla modern kapitalizm arasındaki kopuş kadar radikal bir bölünmenin gerçekleştiğini öne sürmüştür ve ortaya çıkan simülasyon olgusu üzerine yükselen, simülasyona dayanan post modern toplumun ortaya çıktığını savunmuştur (Cevizci, 2011: 1556). Bu bağlamda Baudrillard'a göre, Post modern topluma dair olan bu hipergerçeklik evresine geçiş imgenin dönüşümü bağlamında dört evrede gelişmiştir (Güzel, 2015: 69). Buna göre imgeye özgü çeşitli aşamalar/basamaklar şöyle sıralanmıştır (Baudrillard, 2011: 14):

derin bir gerçekliğin yansıması olarak imge,

derin bir gerçekliği değiştiren ve gizleyen imge,

derin bir gerçekliğin yokluğunu gizleyen imge,

gerçekliğin hiçbir çeşidiyle ilişkisi olmayan, kendi kendinin saf simülakrı olan imge.

Birinci evrede göstergeler, başka bir deyişle sözcüklerle imgeler, gerçekliğin yansımaları olarak işlev görür. Bu bağlamda imge olumlu bir niteliğe sahiptir çünkü imge burada bir tür ayin görevi yapmaktadır (Baudrillard, 2011: 14). Bu evreyi Türkiye tarihi açısında, Tanzimat ve Cumhuriyet'in kuruluşundan 1990'lı yıllara geçen süre olarak ele alınabilir. Bu dönemde dikkat edilirse yazılı basının ve radyonun etkili olduğu, edebiyatın, roman ve şiirlerin gerçekliği entelektüel açıdan yansıttığı bir evredir. Bununla beraber, birinci evrenin belirli bir okur-yazar kesimi ile sınırlı olduğunu vurgulamak gerekir.

İkinci evrede, göstergeler artık hakikati süslemeye, abartmaya ve hatta çarpıtmaya başlarlar. íkinci durumda imge olumsuz bir niteliğe sahiptir. Bu bağlamda imge kara büyü türünden bir şeye dönüşür (Baudrillard, 2011: 14). Bununla beraber ikinci evrede, gerçeklikten mutlak bir kopuş söz konusu değildir (Güzel, 2015: 69). Buna göre görüntü ve imajlar internet, televizyon ve farklı medya aracılığıyla, bizi gerçek imgemizden ayıran ve bize yenilerini veren güç araçlarıdır (Dursun, 2018: 46). Bu evrenin özellikle televizyonun etkisinin yavaş yavaş hissedildiği ve özellikle özel TV kanallarının ortaya çıkmasıyla ortaya çıkan 1990-2005 yılları arası dönem olarak verilebileceği söylenebilir. Bu dönemde medya ve televizyon gerçekliği çeşitli görüntüleri birleştirerek, çeşitli olguları abarttığı çeşitli olguları da önemsiz gösterdiği dönemdir. Örneğin, meşhur "Televole" ve "Magazin programlarında" şişirilen ve abartılan ünlülerin göz kamaştıran yaşamları ve aşkları bunlara birer örnek olarak verilebilir. Veya yakın dönem (2019) dizilerinde romantize edilen aldatma, ihanet sarmalındaki ama birçok insani unsurlar süslenmiş aşk üçgenleri bu durumun diğer bir örneğidir. Çok kolay bir şekilde istenilen kişinin bir öcü, istenilen kişinin kahraman olduğu bu dönem ikinci evrenin tipik bir örneği olarak ele alınabilir.

Üçüncü ve dördüncü evrelerde, göstergeler ve simülasyon bundan böyle gerçekliğin yerini alır ve en nihayetinde sembolik ilişkilerin baskın olduğu sembolik bir topluma geçilir. Bu artık epistemolojik bir hakikat veya gerçeklikten bahsetmenin mümkün olmadığı "Ele geçirilebilecek" tek gerçeklik biçiminin hiper-gerçeklik (hyperreality) olduğu bir aşamadır (Güzel, 2015: 69). Buna göre, artık yalnızca eskisinden daha fazla imge ve temsil yoktur, bu imge ve temsiller bir araya gelerek bize temsil edilmemiş olandan çok daha yakın olan bir gösteri oluşturan şebekeleri oluştururlar. Bu temsili olmayan, yeniden kurulamaz bir soyutlama haline gelmiştir (Irwin, 2011: 384).

Daha detaylı incelendiğinde, üçüncü evrede imge bir görünümün yerini almaya yani bir büyüleme aracı olmaya çalışmaktadır (Baudrillard, 2011: 14). Buna göre, metadan işarete ya da sembole doğru bir kayma süreci ortaya çıktığı, her şeyin taklitlerine göre

| Kastamonu Eğitim Dergisi, 2020, Vol. 28, No. 3| 
kodlandığı bir işaret ile temsil edilmeye başlandığı bir aşama ortaya çıkar (Kartal, 2013: 85). Bu noktada, güzellik, estetik unsurlar, zeka, başarı gibi kavramlar göstergeye evrilmiş, her şey gibi insan bedeni de seyircinin beğenisine sunulan bir meta haline gelmiştir. Bu nedenle birey artık sahneye çıkmış bir oyuncu gibidir ve ona biçilen kurguyu gerçekleştirirken simülasyon evresine geçerek kendi öz benliğine yabancılaşır (Okuyan, 2018: 58). 2004 sonrası yaşadığımız dönem bu evrenin kısmen yansıması olarak ele alınabilir. Günümüzde artık arkadaşlık ilişkilerinin "Facebook" "like” larına dayalı geliştiği, "instagram” takipçisinin sayısının bir sosyallik ölçütü olduğu ve sembolik bir ilişki haline geldiği "Tik Tok" kültürünün ise emeksiz, yeteneksiz sadece dikkat çekme üzerine “hayranlar" kazandırdığı günümüz (2019) Türkiye'si üçüncü evrenin tipik bir örneği olarak ele alınabilir. Baudrillard bu evreyi moda ve giyim endüstrisinin oluşturduğu mal ve hizmetlerden ziyade sembollerle imajların alınıp satıldığı, gerçek birtakım maddi intiyaçları karşılamaktan çok ihtiyaçlarla arzuların psikolojik tatminini sağlanmaya çalışıldığı bir dönem olarak örneklendirmiştir (Cevizci, 2011: 1557). Bu herhangi bir nesneye sahip olmanın toplum içinde itibar görmenin ya da toplumsal bir statünün veya nesnenin bir "gösterge" olarak algılanması anlamına gelmektedir (Adaş, 2018: 13). Bu durum Nasrettin Hoca'nın “ye kürküm ye" fıkrasını anımsatan bir durumun daha ileri bir versiyonudur. Artık değişen hava koşulları veya düzgün ve temiz giyinme ihtiyacının yerini yüksek statülü tasarımcıların etiketleri için duyulan arzu almıştır (Cevizci, 2011: 1557). Bu bağlamda modernleşme sürecinde kapitalizm artık üretim ve teknoloji, yani amaçlar ve araçlar arasında kurulması gereken akılcı ilişkiyi "hiç utanmadan” yok etmiştir (Sarıca, 2018: 10). Çağdaş nesnenin amacı artık fayda sağlamak değildir. Onun amacı "göstermek" tir. Bir araç olarak değil; ancak bir gösterge olarak güdümlenmeye odaklanmıştır (Adaş, 2018: 14). Baudrillard (2011: 80) bu durumu şu şekilde açıklamaktadır:

insanlar her şeyi alıp götürmek, yağmalamak, yemek, yutmak ve güdümlemek istemektedirler. Onlar görme, deşifre etme ve ögrrenme olayıyla pek ilgilenmemektedirler. Kitlesel olan tek duygu güdümleme duygusudur. Organizatörler (sanatçılar ve aydınlar) bu denetlenmesi olanaksız isteksizlikten korkmaktadırlar, çünkü onlar kültürün seyirlik bir olay olmaktan çok öğretici bir şey olduğuna inanmaktadırlar. Anlaşılmaz bir kültüre karşı verilebilecek, bir mabedin kapılarını kırarak tecavüz etmeye benzeyen, bu özgün ve vahşi yanıt, yani bu etkin, yok edici büyülenme olayını göz ardı etmektedirler.

Baudrillard'a göre bir yandan son derece akılcı bir üretim düzeni yaratılırken, diğer yandan akıl dışı bir tüketim düzenine geçilmiştir (Sarıca, 2018: 10). Buna göre, reklamlarda oynayan Türkiye güzeli seçilmiş bir bayan aslında güzelliğini nokta nokta kremi kullandığı için almamaktadır. Tam tersine o bu kremi belki de hayatında hiç kullanmasa bile güzel hale getirmektedir. Bu durum, Twittter, Youtube, Tik Tok gibi herkesin kolayca kanal sahibi olduğu uygulamalarda da kendini başka bir biçimde göstermektedir. Baudrillard (2011: 80) vurguladığı gibi:

insanlar buraya dokunmak amacıyla gelmektedirler. Bakışları dokunur gibidir. Bu bakışlar elle dokunma arzusunun bir parçasıdır. Burası dokunma üzerine oturtulmuş bir evrendir, yoksa görsellik ya da söylev çekme üzerine değil. insanlar günümüzde artık güdümlemek/var olmak, dağıtmak/dağıtılmak, dolaşmak/dolaştırılmak gibi doğrudan yeniden canlandırma, mesafe ya da düşünce düzenine ait olmayan bir sürecin içine sokulmuşlardır. Bu bir paniğe kapılma olayına, paniğe kapılmış bir dünyaya benzemektedir.

Ona göre insanlar kimlik komedisi oynayarak öznel menfaatler uğruna kendilerini tüketmekten başka bir şey yapmamaktalar, kendilerini temsil ettiklerini düşündükleri bir hayaleti yaşatmaktalar (Çimen, 2018: 19). Artık mutluluklar, kızgınlıklar ve öfkeler mavi şeritli bir sayfada temsil edilecek birer işaret olmuştur. Kişinin hangi filmleri sevdiğini, nelere ilgi duyduğunu, arkadaşlarıyla muhabbetlerini, içe dönük mü dışa dönük mü olduğunun, milliyetçi mi yoksa solcu mu olduğunun temel yansıması “öyle olmasa bile" bu sayfalar olmaktadır.

Tüketim toplumundaki bireyin narsisizmi ayrıksılığın hazzı değil, toplumsal niteliklerin kırılıp yayılmasıdır.... Birey her yerde öncelikle kendini beğenmeye, kendinden hoşlanmaya özendirilir. Kendini beğenerek başkalarınca beğenilme şansına ulaşılacağında anlaşılmıştır. En aşırı durumda, kendinden hoşnut olma ve kendi kendini baştan çıkarma, belki nesnel baştan çıkarma erekselliğinin yerine bile geçebilir. Baştan çıkarma işi, bir tür mükemmel "tüketim"de kendi üstüne döner, ama göndergesi daha çok başkasının yargısıdır. Açıkçası hoşa gitme, hoşuna gidilecek kişinin değerlendirmesinin yalnızca ikincil olduğu bir iş haline geldi. Reklamda markanın yinelenen söylemi (Baudrillard, 2012: 103-104).

Artık herkes aktif bir oyuncu olarak kendi izleyici kitlesine kendini sunmak, kendi izleyicisini mutlu etmek ve takipçi kazanmak durumundadır ki böylelikle kendini var edebilsin ve kendi kimliğini oluşturabilsin. Bu durumu ise Baudrillard (2012: 43) şu şekilde açıklamaktadır:

Artık seyirci değil, başarılı ve oyunun akışıyla giderek daha fazla bütünleşen oyuncularız. Dünyanın bir gösteri olarak gerçek dışılığını kaldırabilecekken bu dünyanın aşırı gerçekliği, bu sanal kusursuzluk karşısında savunmasız kalıyoruz. Bu, terörün yeni bir biçimidir; bu terör karşısında yabancılaşmanın sıkıntıları ise neredeyse bir hiçtir...

Dördüncü durumdaysa imge artık görüntü düzenine değil simülasyon düzenine ait bir şeydir (Baudrillard, 2011: 14). Bu aşama, bilgisayar simülasyonuyla atılmış bir aşamadır. Bu aşamada, insan yapımı temsiller dünyasını yalnızca üret(ebil)mek ve tüket(ebil)mekle kalmıyor, fakat artık onları simüle edilebilmektedir (Irwin, 2011: 384-385). Dördüncü evrenin, geliştirilen yapay zekâ programları, sanal gerçeklik uygulamaları ve gözlükleriyle hayatımızı tamamen saracağı bir şekilde geleceği, özellikle beyne yapılan implantasyonlarla bu algının tamamen kontrol edilebileceği bir aşamaya geçebileceği bir "hayal olmadığı" çok rahat öngörülebilir. Bu artık bir şizofreni hastasıyla sağlıklı bir insanın imgeleminin ayırt edilemeyeceği bir evreye doğru yöneldiğimiz anlamına gelmektedir. Buna göre deli taklidi yaparak deli raporu alabilen bir hastanın deliliğin bütün semptomlarını 
gerçekleştirerek doktoru kandırması durumuna benzemektedir (Okuyan, 2018: 75). Dördüncü evreyle ilgili olarak, ekonomik ve sınıfsal ilişkilerin her zaman etkisini hissettireceği eleştirisi bir noktaya kadar doğru olmakla beraber, birçok delüzyonel bozukluk yaşayan insanların kendi gerçekliklerini mevcut gerçekliğin üstüne ve ona rağmen dayatacak şekilde yaşamaları, ilerdeki toplumda bu tür bir şeylerin olabileceğini göstermesi açısından manidar örnekler olarak verilebilir. Böylece, simülasyon 'gerçek' ile 'yanlış' arasındaki 'gerçek' ve 'hayali' arasındaki farkı tehdit eder hale gelmiştir (Dursun, 2018: 17).

$\begin{array}{lll}\text { Derin bir gerçekliğin } & \begin{array}{l}\text { Derin bir gerçekliği } \\ \text { değiștiren ve }\end{array} & \begin{array}{l}\text { Derin bir gerçekliğin } \\ \text { yokluğunu gizleyen }\end{array} \\ \text { yansıması olarak } & \text { gizleyen imge } & \text { imge }\end{array}$

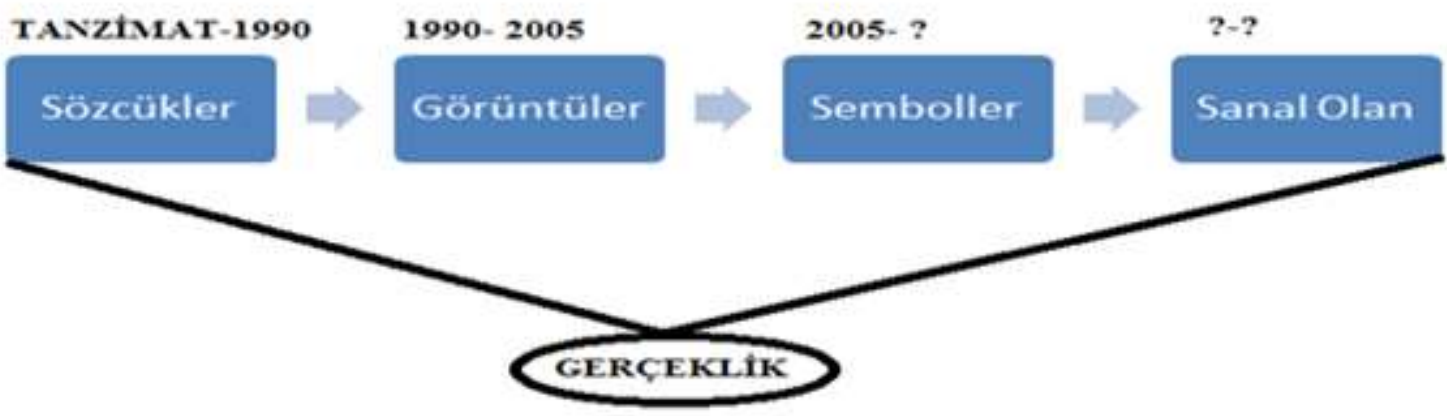

Gerçekliğin hiçbir çeșidiỵle ilișkisi olmayan, kendi kendinin saf simülakrı olan imge

\section{Şekil 1. Gerçekliğin gelişim evreleri}

Baudrillard, postmodern dünyada, en başta iyi ve kötü kavramlarıyla ekonomi, siyaset, kültür ve cinsiyet türünden en temel kavramlar olmak üzere, istisnasız her şeyin öteden beri yürürlükte veya dolaşımda olan anlamını yitirdiğini, kavramların seçikliğinin yitip gittiğini söylemiştir (Cevizci, 2011: 1559). Baudrillard'a göre yabancılaşmanın temel kaynağı meta kültür ve bunun yarattığı meta fetişizmdir. Meta fetişizm bu bağlamda, pazar değerini gösterge şeklinden alan yapısal değer yasası ile kendini ifade eder (Okuyan, 2018: 56). Gerçekliğin yerini tam bir simülasyon evreninin almış ve artık ancak bir hiper-gerçeklik ortaya çıkmıştır (Güzel, 2015: 74). Bu durum şeffaflık dünyasında artık her şeyin ekonomik, cinsel, felsefi ve çok daha önemlisi 1968 yılının sloganlarında ifade edildiği gibi "her şeyin politik" olduğu anlamına gelir. Böylece her şey cinsel olduğundan, artık hiçbir şey cinsel değildir, zira artık cinsellik anlamını yitirmiştir (Cevizci, 2011: 1559). Üçüncü evrede yaşadığımıza ve dördüncü evreye geçiş yapmak üzere olduğumuza göre, Baudrillard'ın kullandı̆̆ı üç temel kavramı açıklamanın ilerleyen analizler için önem arz etmektedir. Buna göre kullanılan üç temel kavramdan simulakr, hakikati gizleyen bir şey olarak değil tam tersine hakikatin kendisi olarak tanımlamıştır. Buna göre, simülakrlar üç gruba ayrılır (Baudrillard, 2011: 127):

- Uyumlu, iyimser ve Tanrı́nın yarattığı ideal doğanın tıpkısını/ikizini oluşturmayı amaçlayan imgeleme, taklit ve kopyalama üstüne kurulmuş doğalcı, doğal simülakrlar ki bunlar ütopya üreten bir düşsellik içerirler.

- Tüm üretim düzenini kapsayan enerji ve güç üstüne kurulmuş, makinelerle somutlaşan, üretici özelliğe sahip, üretken simülakrlar. Evrensel boyutlara insana inanmayı hedefleyen, sürekli bir yayılma eğiliminde olan ve nerede başlayıp nerede bittiği belli olmayan bir enerjiyi özgürleştirme (arzu, göreceli ütopyalarla simülakrlar grubuna aittir) peşinde koşan simülakrlar ki bunlar bilimkurgu üreten bir düşsellik içerirler.

- Information=bilgi, model ve sibernetik oyunlardan oluşan, total bir işlemsellik, hipergerçeklik ve mutlak bir denetimi hedefleyen simülasyon simülakrları ki bunlar artık düşün yerini alırlar.

Simüle etmek, gerçek olmayan bir şeyi gerçekmiş gibi sunmak, göstermeye çalışmak olarak tanımlanmaktadır (Baudrillard, 2011: 7). Simülasyon kavramı gerçek bir toplumdan ziyade, sembollerle imajların, gerçek ve somut olanın yerini aldığı sanal bir gerçeklik olduğunu göstermek amacıyla geliştirmiş olduğu bir kavramdır (Cevizci, 2011: 1557). En genel anlamı ile simülasyon bir kökenden yoksun olan, gerçeğin modeller aracılığıyla türetilmesini simgeleyen aşırı gerçeklik durumu olarak tanımlamıştır (Okuyan, 2018: 2-3). Bunu şu şekilde açıklamıştır (Baudrillard, 2011: 11-12):

Gizlemek (dissimuler), sahip olunan şeye sahip değilmiş gibi yapmak; simüle etmek ise sahip olunmayan şeye sahipmiş gibi yapmaktır... Ancak bu olay sanıldığından daha da karmaşık bir şeydir. Çünkü simüle etmek "-mış" gibi yapmak değildir. "Hastaymış gibi yapan kişi yatağa uzanıp bizi hasta olduğuna inandırmaya çalışır. Bir hastalığı simüle eden kişi ise kendinde bu hastalığa ait semptomlar görülen kişidir" (Littre). Öyleyse "mış" gibi yapmak (feindre) ya da gizlemek (dissimuler) gerçeklik ilkesine bir zarar veremez, yani bunlarla gerçeklik arasında her zaman açık seçik, gizlenmeye çalışılan bir fark vardır. Oysa simülasyon bu "gerçekle" "sahte" ve "gerçekle" "düşsel" arasındaki farkı yok etmeye çalışmaktadır. Simüle eden kişi gerçekten hasta mıdır, değil midir? Çünkü bu insan gerçek semptomlar üretmektedir. Simüle eden kişiye ne hastasın ne de değilsin denebilmektedir. Bu kişiyi nesnel bir şekilde hasta ya da sağlam olarak değerlendirebilmek mümkün değildir. Hakiki bir hastalık olup olmadığı anlaşılamayan bu şey, psikolojiyle tıbbın elini kolunu bağlamaktadır. Çünkü bütün "semptomlar" üretilebiliyorsa ve bir hastalığa ait 
"semptom" "doğal" bir olgu olma özelliğini yitirmişse o zaman her hastalığın simüle edilebileceğini hattâ edilmekte olduğunu düşünebiliriz. Ama o zaman da tıbbın bir anlamı kalmamaktadır çünkü tıp yalnızca nesnel nedenlerini belirleyebileceği "gerçek" hastalıklarla ilgilenmektedir.

Görüldüğü gibi bir simülasyonda, hastalık olmamasına rağmen hastalıkların semptomları üretilebilmektedir. Örneğin, kişi şizofreni hastası olmamasına rağmen en azından biyolojik olarak şizofreni hastalarıyla aynı semptomlara sahip olmamasına rağmen dalmış olduğu simülasyonda bir şizofrenin semptomlarını gösterebilmektedir. Bunun günümüzde kulak altı bluetooth kulaklıklarla yolda kendi kendine konuşan bir kişinin durumuna benzetebiliriz. Fakat Baudrillard'ın bahsettiği simülasyonda artık farklı açılardan anlaşılabilecek gerçekliğin ipuçları bile yok olmaktadır. Bu bağlamda simülasyon herhangi bir şeyin kurgulanarak yeniden öne sürülmesidir (Ada, 2018: 15).

Aslında simülasyon kavramı antik çağlardan beri farklı biçimlerde filozoflarca tartışılmış bir kavramdır. Gerçeklik/görünüş ikilemini tarihte ilk defa konu edinenlerden birisi de Platon'dur. Platon'dan beri bu ikilem felsefi düşüncede varlık alanının sorusu olmuştur. Baudrillard'dan önce simulacrum kavramını ilk kullanan da Platon olmuştur. Platon'a göre bazı masallar, resimler ve şiirler yasaklanmalıdır çünkü bunlar yarattıkları imgelerle halkı yanıltarak (simulacrum üreterek) cumhuriyetten uzaklaşılmasına yol açmaktadırlar. Platon'a göre akılla düşünen insan bir şeyin gerçeğini biliyorsa onun gölgesinin gölgesi olan imgesiyle ilgilenmemelidir (Sarıca, 2018: 16).

Platon'nun meşhur mağara alegorisinde tartışılan hakikat ve zan arasındaki tartışmanın Baudrillard'da bambaşka bir forma dönüştüğü söylenebilir. Platon gerçeklik ve görünüşler dünyasını incelerken fenomenler ve idealar dünyası adını verdiği iki ayrı dünya öne sürmüştür: "Fenomenler dünyası" varlığı, görünüşü temsil ederken, "idealar dünyası” düşünceyi, ontolojiyi ve gerçeği temsil etmektedir (Okuyan, 2018: 61). Platon alegoriyi daha ziyade okuyucuya daha yüksek bir hakikat düzeyini, fikirlere ya da formalara işaret etmek için kullanır. Buna göre bizler sık sık içinde yaşadığımız gerçekliğin var olan en yüksek hakikat olduğunu varsayma hatasına düşerek mahkûmlara benzeriz (Irwin, 2011: 24). Zincirlerimiz bağı bulunduğumuz varsayımlarımızdır. Hatırlanacağı üzere mağara alegorisinde bir mağaranın içerisinde zincirlenmiş ve tek bir duvara bakan köleler ve bu kölelere mağaraya yansıyan güneşışığından faydalanarak çeşitli nesnelerin yansımalarını sunan kişiler bulunmaktaydı. Platon’a göre, bu mağaranın duvarındaki gölgeler de gerçektir; fakat daha gerçek olan nesnelerin gölgeleridir (Okuyan, 2018: 62). Buna göre, köleler zincirlerini koparıp aslında gölgelerin gerçek kaynağının güneş ve cisimlerin gerçek aslını sembolize eden fikirler olduğunun farkına varmaktadırlar. Bununla beraber karanlığa alışmış oldukları için güneş ışığı yani hakikatin ışığı onların gözlerini acıtmaktadır. Burada Platon'un bahsetmiş olduğu temel fikir, olgular dünyasından kavramlar ve fikirler dünyasına geçişin zorlu ve zahmetli bir süreç olduğu ve bunu elde etmenin güç olduğu şeklindedir. Bu bakımdan yorumlandığında Platon' un sözünü ettiği gölgeler simülakra denk düşmektedir (Ada, 2018: 15). Bununla beraber, Baudrillard bu mağara alegorisindeki gölgelerin artık gerçek olduğunu ve herhangi bir temele yani fikir ve ideaya dayanmadan üretildiğini söylemiştir. Bu durumu (Baudrillard, 2011: 15) şu şekilde açıklamaktadır:

Bir şeyleri gizleyen göstergeler aşamasından gösterilecek bir şey kalmadığını gizleyen göstergeler aşamasına geçiş bir dönüm noktasıdır. Çünkü birinciler ideolojilere özgü bir hakikat ve sır teolojisine gönderirken; ikinciler bir simülasyon ve simülakrlar çağına girilmiş olduğunu, artık ortada ne kendi kullarına sahip çıkabilecek bir Tanrı, ne de gerçekle sahte ve gerçekle yapay bir yönteme başvurularak diriltilmiş 'gerçeğin' birbirinden ayrılmasını sağlayacak bir Kıyamet Günü olasılığı bulunmadığını söylemektedirler. Çünkü her şey zaten ölmüş ve Kıyamet Günü beklenmeden diriltilerek yaşama döndürülmüştür.

Baudrillard'ın farklı şekilde kurguladığı nihilizminde ve üslubundaki, ironik ve sert dildeki Nietzsche'vari belirtiler, Nietzsche'nin onun hayatındaki etkisinin izleridir (Okuyan, 2018: 46). Bu etkiyi yukarıdaki paragrafının aslında en yüksek hakikatin ölüm ilanını ifade eden Nietzsche'nin, "Böyle Buyurdu Zerdüşt" adlı eserinde, Zerdüşt'ün dağdan yalnız olarak indiğinde bir ihtiyarla karşılaştıktan sonra yalnız kalınca, kendi kendine söylediği o meşhur sözüyle ilişkisi göz önüne alındığında daha iyi anlaşılmaktadır (Nietzsche, 2010: 35):

Mümkün olabilir mi böyle bir şey? Henüz işitmemiş olabilir mi, ormanda yaşayan bu mukaddes ermiş, tanrının öldüğünü?

Bu ölüm Tanrı́nın olmadığı veya gerçekten öldüğü anlamına gelmemektedir. Bu Tanrı fikrinin bir insanın zihin dünyasında ölümünü ifade etmektedir. İşte bu nedenle 'Tanrı öldü' diyen Nietzsche'ye, Baudrillard: "Tanrı ölmedi, hipergerçek bir hal aldı” yanıtını veriyordu. Bu bağlamda, Baudrillard simülasyon düzeninde Tanrının da kusursuz bir şekilde yok edildiğini, varlığının sorusunun üstünün örtülmüş olduğunu bunun ikonların vasıtasıyla yapıldığını iddia etmiştir (Dağ, 2009: 98). Baudrillard (2012: 172-173) şunları vurgulamaktadır:

Eskiden, inanabileceğimiz nesneler, inanç nesneleri vardı. Bunlar yok oldu. Ama inanmamamız -ilki denli yaşamsal bir işlevgereken nesneler de vardı. Bunlar, geçişli, bir anlamda alaycı, duyarsızlığımızın nesneleriydi, ama yine de nesneydiler. Ideolojiler bu rolü oldukça iyi oynuyordu. Onlar da kayboldu. Ve artık, yalnızca haber adı altında dolaşan her şeyi içine alıp eritmekle kalmayan, aynı zamanda haber ilkesine ve aşkınlığına da inanmaya dayanan toplu saflığa ilişkin tepkeli bir eylem aracılığıyla yaşamda kalıyoruz. Bu bir tür tepkeli uzlaşmaya yönelik köklü inançsızlığımızı ve direncimizi de koruyarak yapıyoruz bunu. Toprak kölelerinin, ilahi hakkın köleleri olduğuna hiçbir zaman inanmadıkları gibi, bizler de haberin ilahi bir hak olduğuna inan mıyoruz, ama inamyormuş gibi yapıyoruz. Bu 
perdenin gerisinde dev bir inançsızlık, gizli bir duyarsızlaşma ve her türlü toplumsal bağın yadsınması ilkesi büyümekte.

Buna göre bireyin yüceltildiği, çağımızda dayanak arayan sıradan insan ise, ekrandan sunulan bu ikonlara sorgulamadan tapar hale gelmiştir. Bu bir bakıma modern putperestliğin başka bir ifadesidir. Eski dönemde insanlar ikon olarak gördükleri liderleri önemli kişileri zamanla nasıl birer tanrı olarak puta dönüştürmüşse günümüzde ki metalar bu şekilde birer puta dönüşmüştür. Artık Platon'un mağarasındaki insanların zihinleri ikonlar aracılı̆̆ıla zincirlenmiş ve düşünemez hale gelmiştir. Tam da bu metafizik bağlamında Baudrillard (2011: 10) şunları vurgulamaktadır:

Burada ortadan kalkan şeyin adı metafiziktir. Bundan böyle bir varlıkla çeşitli görünümleri; gerçekle gerçek kavramına özgü bir ayna/yansıma (metafizik) olmayacaktır. Bundan böyle gerçekle gerçek kavramı arasında düşsel bir beraberlik de olmayacaktır. Çünkü genetik minyatürleştirme denilen şey, simülasyon evrenine özgü bir boyuttur. Günümüzde gerçek artık minyatürleştirilmiş hücreler, matrisler, bellekler ve komut modelleri tarafından üretilmektedir. Bu sayede gerçeğin sonsuz sayıda yeniden üretimi mümkün olmaktadır. Bundan böyle rasyonel bir gerçeğe ihtiyacımız olmayacaktır zira "gerçek" ideal ya da negatif süreçlerle başa çıkabilecek (boy ölçüşebilecek) bir durumda değildir. Artık işlemsel bir gerçek vardır. Aslında gerçek bu değildir çünkü onu sarıp sarmalayan bir düşsellikten yoksundur.

Böyle bir simulasyonda simulakr’ın bırakcağı etki ise artık gerçeğin yerine geçmiş bir hiper-gerçekliktir. Sizek (2012: 44) bu durumu şu şekilde açıklamaktadır:

Bostan korkuluğu bizi bir simulakrumun etkili oluşuyla karşı karşıya getirir: Bostan korkuluğu kargaları korkutur, çünkü rüzgârda dalgalanıp sallanır; bostan korkulukları insanları korkutur çünkü bir insanı taklit etmedeki başarılarının çöküşü, bazen âni ve ürkütücü bir şekilde, bir insanın simulakrumu olduklarının belirtilerini açığa çıkarır. Bostan korkuluklarını dehşet verici kılan şey onları insanlık dışı/içi kılan asgari farktır: Maskenin ardında "evde kimse yoktur" - zombiye dönüşmüş bir insanda olduğu gibi.

Baudrillard'a göre simülasyon içerisinde bireyler için, televizyon aracılı̆̆ıyla kendisine haber olarak aktarılan bir iç savaş görüntüsüyle, bir deterjan reklamı aynı etkiye sahiptir çünkü her ikisi de işlemsel evreleri açısından birbirlerinden daha değerli ya da değersiz değillerdir. Bireyin olan biten her şeyi aynı duyarlılıkla yaşadığı bu evren simülasyon evrenidir (Sarıca, 2018: 22). Sonuç olarak kayıtsızlığın hüküm sürdüğü bu aşamada bütün ruhsal gerçeklikler sanal bir dünyanın elinde simülasyonun hakimiyetine verilecektir. Tüm yüksek teknoloji düzeyi, insanoğlunun kendi kopyalarının ve protezlerinin, biyolojik kopyalarının ve sanal görüntülerinin ardında kaybolmak için bunlardan yararlandığı olgusunu örneklendirir (Okuyan, 2018: 58).

\section{YÖNTEM}

Bu çalışmada nitel araştırma modeli kapsamında doküman incelemesi yapılmıştır. Bir olay ya da sürecin, birey ya da gruplar tarafından farklı şekillerde alınan kayıtları doküman olarak tanımlanmaktadır. Online arşiv kaynakları da doküman olarak nitelendirilmektedir. Karasar'a (2008) göre doküman incelemesi geçmişteki olguların izlerini taşıyan resim, film vb. yapıtları, olgularla ilgili olarak yayınlanmış kitap, dergi vb. birtakım yazılı materyalleri analiz etmek için kullanılan nitel araştırma yöntemidir. Buna göre öncelikle konuyu ilgilendiren kayıtlar toplanmış, belirlenen kriterler göz önüne alınarak incelenmiş ve değerlendirilmiştir (Ekiz, 2009). Çalışma kapsamında, Baudrillard'ın temel eserleri ışığında YÖK Ulusal Tez Merkezi'nde yer alan lisansüstü tezler incelenmiş ve çeşitli Türkçe makaleler üzerinden yorumlama yapılmıştır. Eserler seçilirken özellikle başlığında veya özetinde Baudrillard'ın isminin veya Baudrillard'ın simülasyon ve simulakr kavramlarının olması göze alınmıştır. Ayrıca eserin içeriğinin de doğrudan Baudrillard'ın felsefesiyle ilişkili olmasına özen gösterilmiştir.

Veriler analiz edilirken öncelikle bir araştırmacı tarafından toplanan ilişkili yorum ve cümleler komposizyon şeklinde yazılmıştır. İkinci aşamada ise diğer iki araştırmacı tarafından ilgili literatür bağlamında komposizyon tekrar düzenlenmiştir. Son aşamada ise yazı tekrar ilk yazar tarafından yorumlanmış ve her üç yazarın düzenlemesiyle son halini almıştır.

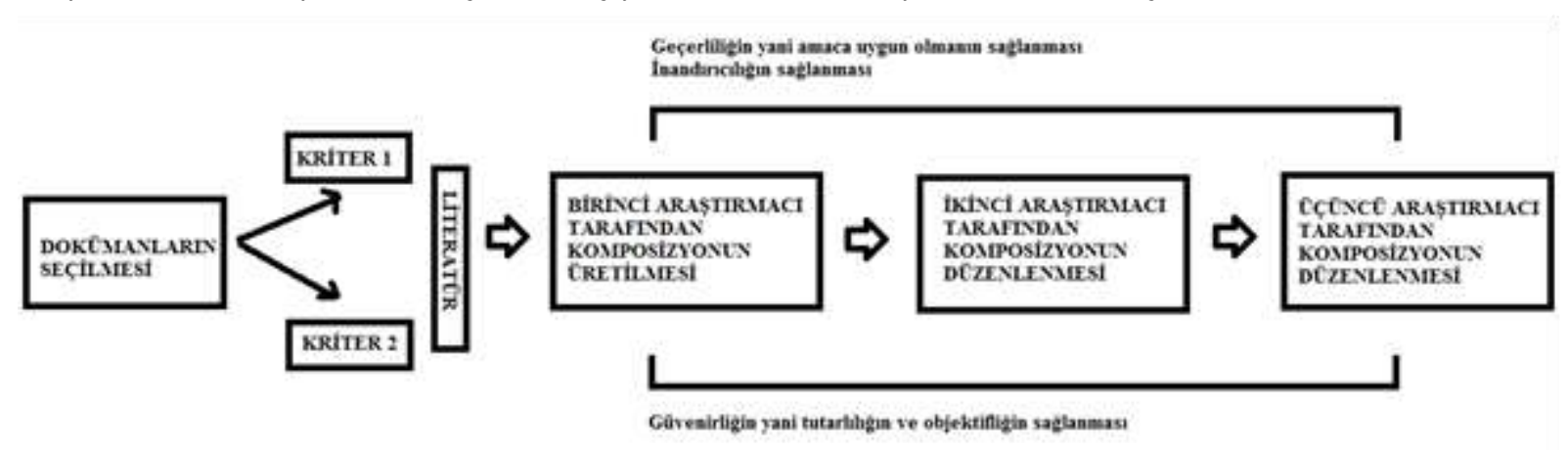

\section{Şekil 2. Araştırmanın modeli}

Literatürün Baudrillard’ın temel eserleri hariç çoğunlukla Türkçe kaynaklardan alınmasının nedeni, Baudrillard’ın görüşlerinin Türk kültürü bağlamında bir perspektifle okumanın Türkiye'deki eğitim ve eğitim programı anlayışına daha özgün ve anlamlı cevaplar ortaya koyabileceği varsayımıdır. Bu bağlamda aşağıdaki sorulara yanıt aranmıştır: 
1. Baudrillard'ın görüşleri açısından eğitim kavramı nasıl yorumlanabilir?

2. Baudrillard'ın görüşleri açısından genelde eğitim programı kavramı özelde ise Türkiye'deki eğitim programları nasıl yorumlanabilir?

\section{BULGULAR}

Bu bölüme Baudrillard'ın görüşleri açısından genel olarak eğitim kavramın özel olarak ise Türkiye'deki eğitim programı yorumlanacaktır.

\section{Baudrillard'ın Görüşleri Açısından Eğitim Kavramının Yorumlanması}

İlk bölümde bahsedildiği üzere, Baudrillard, hiper-gerçekliğin, yani medyanın gerçeklik simülasyonlarının, Disneyland’lerin ve başkaca eğlence parklarının, TV sporlarının vs. gerçek olandan çok daha gerçek hale geldiğini söylemiştir. Bu ise elbette hipergerçekliğin düşünceyi ve gerçekliği kontrol etme düzeyine geldiği anlamına gelmektedir (Cevizci, 2011: 1560). Bu bağlamda Jean Baudrillard'ın postmodern yaşımızdaki işaret, sembol ve simulasyon karakterinin radikal olarak sorgulaması, çağdaş eğitim uygulamalarının bu bağlamda değerlendirilmesi açısından önemlidir. Baudrillard'ın simülasyon kuramı soyut ve somut olanın değil; gerçek ile taklidin savaşıdır. Taklitlerin gerçeğin yerini alması; yapay olanın hakiki olandan ayırt edilememe durumunun sonucu olan hiper-gerçekliği ortaya çıkartır (Okuyan, 2018: 3). Baurdrillard (2011: 33) bu durumu şu şekilde ifade etmektedir:

Çağımızdaki temel hastalığın adı: Gerçeğin üretimi ve yeniden üretimi denilen şeydir. Ekonomi politiğin altın yıllarına özgü diğer üretim çeşitlerinin: Değer üretimi, mal üretimi, vb.'nin ne zamandır bir anlamı kalmamıştır. Uzun yıllardan bu yana toplumun hiç durmadan üretip, yeniden can vermeye çalıştığı şey, işte o elinden kaçırmış olduğu gerçektir. Işste bu yüzden "maddî" üretimin bizzat kendisi günümüzde hiper-gerçek bir şeye dönüşmüştür.

Bu üretim sürecinden eğitimin ayrı bir biçimde ele alınamayacağı bu bağlamda söylenebilir. Bu noktada bilginin üretiminin imgenin üretimiyle paralel bir şekilde ele alınabileceği söylenebilir. Bu bağlamda bilgi geçmişten günümüze kadar dört aşamadan geçecek şekilde üretilmiştir:

- $\quad$ derin bir gerçekliğin yansıması olarak bir zanaatın bilgisi

- $\quad$ derin bir gerçekliği değiştiren ve gizleyen bir zanaatın parçası olan bilgi

- $\quad$ derin bir gerçekliğin yokluğunu gizleyen parçalanmış bilgi

- $\quad$ gerçekliğin hiçbir çeşidiyle ilişkisi olmayan, kendi kendinin saf simülakrı olan bilgi

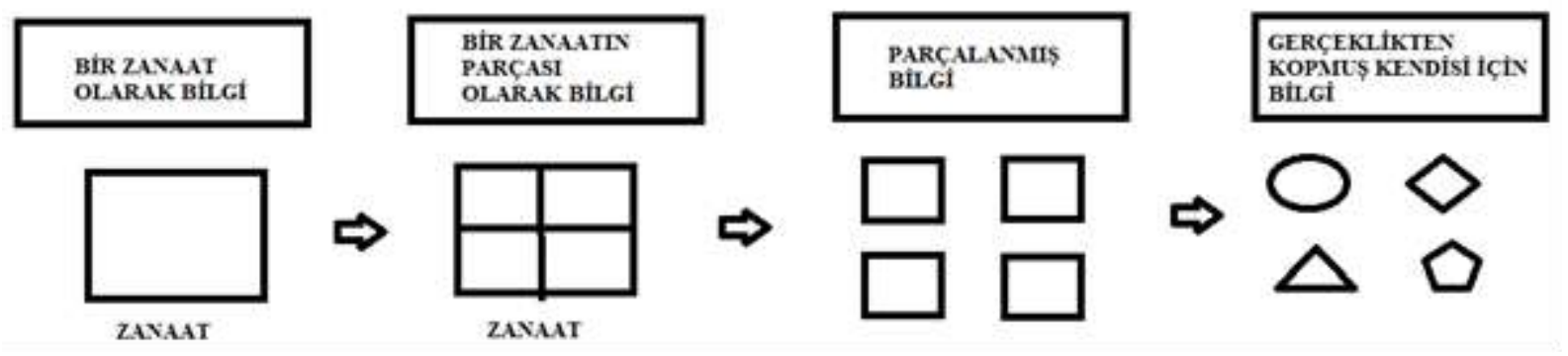

\section{Şekil 3. Bilginin simulakra dönüşümü}

Derin bir gerçekliğin yansıması olarak bilgi aşaması insanlık tarihinin bu dönemi, 18. Yüzyılda başlayan sanayi devriminden önceki döneme işaret eder. Sanayi çağından önce, hemen hemen her yerde örgün eğitim verilmesi az rast-lanan bir şeydi ve genellikle gönüllülük esasına dayalı ve genellikle erkekler ile sınırlıydı. Eğitim, feodal Avrupa'da kiliseye aitken, Osmanlıda medreselerde yürütülmekteydi (Carl, 2009). Burada bilgi türü bir şeye verdiğimiz anlam (“sembolik") ile temsil ettiği gerçeklik arasında doğrudan bir ilişki vardır. Örneğin, bir sandalyenin yapılması yapım araçlarının baskın bir şekilde ön plana çıkmasına gerek kalmadan üretilen bir zanaatkârın eseriydi. Sandalye üretimi için bazı farklı tekniklerin kullanılması için günümüzdekine benzer bir şekilde süreci hızlandırmak veya kolaylaştırmak için çeşitli stratejiler ve yöntemlere gerek yoktu çünkü her sandalyenin ayrı ayrı ve elle yapılması gerekiyordu. Sandalye ile temsil ettiği sembolik önem arasındaki doğrudan korelasyon nedeniyle (zaman, iş ve uzmanlık yatırımı), sandalyeye yapan herkes anlamını çabucak anlayabilir ve "okuyabilirdi”. Benzer şekilde, daha soyut olarak düşünülebilecek hukuk, din veya felsefe de bilginin bu somutluğu üzerinden inşa edilmiş bir metafiziği yansıtıyordu. Öğrenci olmak demek belirli bir pratik düzelmede ihtisas sahibi olmak demekti. Zaten eğitimde günümüzdeki gibi herkesin bir şekilde dahil olmak zorunda olduğu bir durum değildi. Medrese veya çeşitli manastır veya yükseköğretim kurumlarında verilen eğitim sınırlı bir kesimin devlet yönetimi, hukuk, maliye, din konusunda yetiştirmeye dönük bir şekilde ortaya çıkmıştı. Çoğu insan kırsal kesimde 
yaşamaktaydı ve yaşamlarını idame ettirmek için gerek duydukları bilgi de hayvancılık, tarım alanında gerek duydukları deneyimsel ve geçmişten gelen pratik bilgilerdi. Bunun dışında ise gerçeğin daha ideal durumunu temsil eden "öteki dünyaya" ilişkin dini bilgilerin pratik malumatına ihtiyaç duyulmaktaydı. Bu bağlamda ister somut ister soyut olarak ele alınsın bilgi bir zanaatın bilgisini ifade ediyordu. Bu zanaatın bilgisi genelde usta-kalfa-çırak ilişkisi içerisinde nesilden nesile aktarılıyordu.

Derin bir gerçekliği değiştiren ve gizleyen bilgi ise Fransız Devrimi sonrası ulus devletlerin ortaya çıkması ve erken sanayi devrimi ile çakışan kabaca 18. ila 19. yüzyılların ortalarına işaret etmektedir. Bu aşamada, bilginin sembolik anlam dağılmaya ya da parçalanmaya başlar ve gerçeklikle olan ilişkisi daha zayıf hale gelir. Bu senaryoda, bir sandalye hala yetenekli bir zanaatkâr tarafından tasarlanıp üretilir. Bu aşamada, sandalye (belirleyici) ile zaman, iş ve uzmanlık yatırımı (belirtilmiş) arasındaki doğrudan bağlantı verimlilik için feda edilir. Her ne kadar birden fazla sandalye montaj hattından hızla çıkabilse ve daha fazla kişiye dağıtılıp satılabilse de üretilen her bir sandalye yalnızca birinci dereceden sandalyelerin taşıdığı "anlamın" bir parçasını içermektedir. Bu bağlamda orijinal ustadan çok daha fazla sandalye üretebilen her fabrika çalışanı sadece işin bir bölümünü gerçekleştirebilecek bilgiye sahip olur ve hiçbiri bu işin zanaatına sahip olamaz. Bu nedenle ilk aşamayı karakterize eden "işaretlenmiş bilgi" şimdi fabrikada üretilen tüm sandalyeler arasında dağılmıştır, bu nedenle her "işaretçi bilgi" daha az güçlü, daha az "gerçek" olur. Bu tür bir yerinden etme ve parçalanmayı içerir. Bu zanaatkârlığın yerinin montaj hattı uzmanı olmanın aldığı bir durumdur. Tam bu noktada zanaatkârlığın sandalyeye ilişkisi parçalanmış ve dağılmış olduğu için gizlenir. Artık fabrikada beraber çalışarak sandalye üreten ama kendi başlarına kaldıklarında bir sandalyenin parçasından öte sandalye hakkında bilgisi olmayan işçiler vardır. Bilginin kendisini bu şekilde gizlemesi sadece sanayileşme sürecinde kendini göstermez. Artık hem ulus devletlerin ortaya çıkışyla ve devlet bürokrasisinin daha örgütlü bir yapı haline gelmesiyle hem de açılan fabrikaların en azından okuma yazma bilen, bir makineyi kullanabilmek için gerekli temel becerilere sahip bireylere gerek duyulur. Bu nedenle örgün eğitim kurumlarına ihtiyaç duyulur. Fabrikada veya devlet bürokrasisinin adabını bilen ve bu yapının kimliğine sahip bireylere ihtiyaç vardır. Bu bağlamda bilgi bir zanaatın bilgisinden ziyade montaj bilgisine dönüşür. Bu bilgi türü temel olarak tekrar ve taklide dayanan bir bilgidir. Gözlemlenebilir, ürün odaklı ve bireyi de nesneleştiren bir anlayış içerir. Belki de böyle bir anlayış içerdiği için bu dönemde özellikle Avrupa'da buna bir tepki olarak Mason locaları ortaya çıkmaya başlamış ve bu parçalanmış bilgi anlayışının en azından aristokrat sınıflarda soyut bir zanaat olarak aktarılması hedeflenmiştir çünkü sonuçta insan makine değildir ve kendisini ancak bir zanaat içerisinde keşfederek, üreterek var kılar.

Derin bir gerçekliğin yokluğunu gizleyen bilgi aşaması ise 19. yüzyılın sonlarından 20. yüzyılın sonlarına kadar oluşan endüstriyel çağın zirvesine denk gelir. Bu aşamada, mekanizasyonun yaygınlaştırılmasında başka bir şey olur: nesneler başlangıçta güzelliği veya kalitesi için hatta çoğu zaman orijinal kullanımları için değil kolaylığı için ilk prototiplerinden yaratılmaya başladılar. Tıpkı lezzet veya besin değeri yerine uzun mesafelerde gönderilebilmeleri nedeniyle yetiştirilen meyve ve sebzelere benzetilebilir. Bu bağlamda tüketimi yönlendiren şey zorunlu olarak ihtiyaç değil, pazarlama ve reklamcılık olmaya başlamıştır. Bu aşamada, ürünün kendisi artık bir "pazarı" doldurmak için ilk anlayışından yola çıkarak tasarlanan bir "ürün" olarak ortaya çıkmaya başlamıştır. Bu bağlamda, soluk ve yırtık pantolonlar dahi moda olarak pazara sunulabilmekte ve satılmaktadır. Bu aslında her bir özelliği ve gerekçesi zaten fabrikanın üretim yeteneği tarafından şekillendirilen nesnelerin üretimine işaret eder. Benzer durum eğitim için de geçerlidir. Artık eğitimin ürünü olan insan belirli bir zanaatı öğrenmek ve üretmek için eğitilmemekte tam tersine belirli bir pazarı ve tasarımı gerçekleştirmek amacıyla eğitim sürecine girmektedir. Başka bir deyişle eğitim bir tüketim nesnesi haline gelmiştir. Fakat bu tüketim basit ve pasif bir sindirme değildir. Baudrillard (2014: 240) bu tüketim anlayışını şu şekilde açıklar:

\section{Tüketimi gerçekten de bizim sanayi toplumumuza özgü bir biçim olarak görebiliriz. Doğal olarak onu herkesin bildiği gereksinimleri tatmin etme süreci olarak görme gibi bir tanımı dışlamak koşuluyla. Çünkü tüketimi, üretim adlı aktif süreçle karşılaştırarak pasif boyun eğme ve satın alma biçimi gibi görmek ve buradan yola çıkarak basit davranış (ve yabancılaşma) şemaları oluşturmak doğru bir şey değildir. Ilk baştan itibaren tüketimi, tüm kültürel sistemimizin üstüne oturduğu (yalnızca nesnelerle değil aynı zamanda toplum ve dünyayla) aktif bir ilişki kurma biçimi, sistemli bir etkinlikler dünyası ve sorulara yanıt verme biçimi olarak görmek gerekmektedir.}

Bu bağlamda İngilizce, iletişim kurmak, Shakespeare okumak veya İngilizce literatürde bilimsel gelişmeleri takip etmek için öğrenilen bir dil olarak değil piyasada daha iyi iş bulabilmek, akademik veya mesleki ünvanları daha kolay elde etmek, güzel sarışın bir bayanla tanışmak için öğrenilmesi gereken bunun içinde belirli örüntüde tasarlanmış sınavları geçerek elde edilebilecek bir tüketimsel "beceri" haline gelmektedir. Benzer şekilde belirli bir sertifikaya sahip olmak o sertifikanın ilgili olduğu alanda örneğin aile danışmanlığı alanında sorun çözebilen bir yeterliliğe sahip olmaktan ziyade kendini o alanda bir yeterliliğe sahip göstermenin bir aracı haline gelmiştir. Yurtdışında eğitim almak, "ilim Çin'de de olsa" alma amacından ziyade "yabancı" ve "iyi" bir üniversitede sükseli bir diplomanın ve bu diplomanın açacağı kapıların anahtarı anlamına gelmektedir. Bu bağlamda bireysel olarak yeni şeyler öğrenmek ve üretmekten ziyade, bu anahtarları en uygun kişi ve kurumlarla elde etmek temel amaç olmaktadır. illginçtir Nurettin Topçu (2017)'da bu durumu çok önceden görmüş ve eğitim sisteminin bir ilim artık ilim yolculuğu diploma avcılığına döndüğünü şu şekilde vurgulamıştır:

| Kastamonu Eğitim Dergisi, 2020, Vol. 28, No. 31 
Maarifimiz büroya memur, eski tabiriyle kalem efendisi yetiştiriyor. Bugün talebelik artık ilim yolculuğu değil, diploma avcılığıdır. Mektebe gelince o artık ne mabet ne yuva ne de ocaktır. Sadece ders odalarının bütününden ibaret bir devlet dairesidir. Biraz da kulüp, sahne, yardım müessesi, kahve ocağı ve alışveriş yeridir.

Bunun temel nedeni ise diplomanın bir tüketim nesnesi olarak sembolleşmesidir. Artık İngilizce konuşamadığı, yazamadığı halde İngilizce sertifikasına sahip olma, bir şeyi keşfetme aşkı yaşamadan akademisyen olmak, tüketmediği bir nesnenin zoraki pazarlamacısı olmak bu sistemin eğitilmiş insandan beklediği temel özelliktir. A özel okulu çok kötü olmasına ve sadece paraya odaklanmasına rağmen orada çalışmak zorunda kalan öğretmen okulunu en iyi şekilde pazarlamak zorundadır. Baudrillard (2013:87)'nin vurguladığı gibi “tüketim toplumu aynı zamanda tüketimin öğrenilmesi toplumu, tüketime toplumsal bir biçimde alıştırılma toplumudur. Yani yeni üretim güçlerinin ortaya çıkmasıyla ve yüksek verimlilik taşıyan ekonomik bir sistemin tekelci yeniden yapılanmasıyla orantılı yeni ve özgül bir toplumsallaşma tarzı” nın yansımasıdır bu.

Elindeki makyaj malzemeleri sağlığa zararlı ve kalitesiz olmasına rağmen bunun tanıtımını yapan bayan güzelliğini bunlara borçlu olduğunu söyleyerek kendini maskelemek de bu eğitimin bir parçasıdır. Hiç umurunda olmadığı insanları sağlıkları açısından önemli olduğunu öne sürerek diş sigortası, sağıık sigortası almaya ikna eden banka operatörünün durumu da aynıdır. Bu bağlamda eğitim de bir tüketim nesnesi haline gelmiştir. Artık eğitim sadece bir iş bulma kapısı olarak değil, bu işin bireyi sisteme nasıl entegre ettiğini gösteren bir anlama da gelmektedir. Bu eğitimin metalaşması olarak adlandırılan durumdur. Buna göre, İngiltere'de okumak İngiliz vatandaşı olmanın ve iyi bir gelire sahip olmanın anahtarıdır. ABD'de eğitim almak öğrenerek gelişmeden ziyade Amerikan filmlerindeki Amerikan rüyasına açılan kapının ilk adımıdır. Baudrillard (2013: 16) bu durumu şu şekilde açıklıyor:

Kurt çocuğun kurtlarla yaşaya yaşaya kurda dönüşmesinde olduğu gibi demek ki biz de yavaş yavaş işlevselleşiyoruz. Nesneler çağını yaşıyoruz: Söylemek istediğim, nesnelerin ritmine ve onların hiç kesintisiz art arda gelişine göre yaşadığımız. Geçmiş uygarlıkların tümünde dayanıklı nesneler, araçlar veya binalar kuşaklarca insandan daha uzun yaşamışken, bugün onların doğmasını, gelişmesini ve ölmesini izleyen bizleriz.

Baudrillard'a göre metaların artık birer değer işaretleri vardır ve bu değer yeni toplumsal formasyona egemen kurallar, kodlar ve toplumsal belirli bir mantık tarafından belirlenmektedir. Örneğin, prestij markalarında olduğu gibi bazı metaların işaret değeri diğerlerinden daha yüksektir ve tüketim toplumları bu işaret değerleri hiyerarşisi tarafından belirlenmektedir. Benzer şekilde bireyin diğer bireylerle ilişkisi, toplumsal konumu ve prestiji büyük ölçüde bu değer işaretleri tarafından belirlenmektedir (Kartal, 2013: 58-59). Baudrillard (2013: 15) bu durumu şu şekilde açıklamaktadır:

Bugün tüm çevremizde nesnelerin, hizmetlerin, maddi malların çoğaltılmasıyla oluşturulmuş ve insan türünü $n$ ekolojisinde bir tür temel dönüşüm oluşturan akıl almaz bir tüketim ve bolluk gerçekliği var. Daha doğrusu, bolluk içindeki insanlar artık, tüm zamanlarda olduğu gibi başka insanlar tarafından değil, daha çok NESNELER tarafından kuşatılmıs durumda. Bu insanların gündelik alışverişi benzerlerinin eskiden yaptığı alışverişe benzemiyor; daha çok, istatiksel olarak yükselen bir eğriye göre mal ve iletilerin edinilmesi, algılanması ve güdümlenmesi biçimini taşıyor.

Eğitim almada bu noktada belirli değer işaretleri tarafında belirlenen bir meta haline gelmektedir. Öss'de yüzdelik dilimlerdeki yerleşme sıraları incelendiğinde yıllar içinde tercih sıralamalarının pek değişmediği görülmektedir. Buna göre öğrenci bireysel yetenek ve ilgi alanından ziyade mesleğin toplumsal statüsü ve getireceği işareti satın almakta ve daha sonra "nasıl olsa çap yaparım veya lisansüstü bir şeylere bakarım mantığıyla" belirli bir tercih şablonuna yönelmektedir. Bu aşamada artık sembolik görünüm sadece görünüşte oynayan ve arkasında gerçek olan hiçbir şeyin olmadığı gerçeğini kapsayan bir yapıdadır çünkü ana işlevi, derin bir gerçekliğin yokluğunu "[...] maskelemektir". Bu gizleme kendisini günümüzde Türkiye'sinde en güzel olarak akademik kariyer ve üniversiteye hazırlık sürecinde göstermektedir. Eğitim sistemi ve onu destekleyen medya, bireyleri sürekli lisans, yüksek lisans, doktora, yabancı dil öğrenme, kendini geliştirme gibi bunların tamamı bireyin kendi iradesi ve gücüne bağlı şeylermiş gibi sunduğu kişisel gelişim simulakrları sunarken, eğitim sistemi simülasyonu ise işsizliğin ertelenmesinde hem bireylere hem de ailelere belirli bir süreliğine de olsa "çocuğumuz öğrenci" algısını yaratmaktadır. Bu aslında hiç var olmayan ve olmayacak olan beklentiler üzerine inşa edilmiş simulakr insan tipinin ortaya çıkmasına neden olmaktadır. Lisans okumasına rağmen lisans okumayandan veya başka bir dalda çalışanla aynı işte çalışacak veya çalışamayacak kişinin aslında eğitiminin arkasındaki "yokluğu" gizleyen bir durumdur bu. Eğitimsiz ve hiçbir üretimi olmayanların bir şekilde yükselirken, torpilin, ailesinin veya çeşitli grupların kapital birikiminin yükselttiği insanların karşısında içlerinden sıyrılarak çoğu zaman da gerçek hikâyeleri gizlenen çok az sayıdaki çobanken doktor olan fakir ama zeki öğrencinin başarısı altında milyonlarca insanın başarısızlık ve dramının örtüldüğü bir durumdur bu.

Baudrillard metayı yalnızca maddi bir nesne olarak değil, bir iletişim aracı, bir işaret olarak değerlendirerek daha radikal bir perspektiften analiz etmiştir. Baudrillard'a göre, tüketim yalnızca ihtiyaçların karşılanması yoluyla pasif üretim alıcısı değil, "bireylerin" yaratılması ve sisteme entegrasyonu için "işaretlerin manipülasyonu” konusunda aktif bir çabadır (Mendoza, 2010: 47-48). Bu bağlamda eğitim artık bir şey olmanın işareti bir meta haline gelmektedir. Zaten Baudrillard’ın hiper-gerçeklik kavramını 
geliştirme amacı, çağdaş dünyanın gerçek bir toplum oluşturmadığını ve gerçekliğin veya hakikatin yerini sanal bir gerçekliğin aldığını böylece insanların maddi ihtiyaçlarını karşılamaktan çok, bu imajlar ve sembollerin temini ve semboller aracığı ile bir tür psikolojik tatmin sağlama yoluna gittiğini göstermektir (Güzel, 2014: 52-53). Baudrillard (2013: 20) bu durumu şu şekilde açıklıyor:

"Tüketim" in tüm yaşamı kuşattığı, tüm etkinliklerin aynı bileştirici biçime uygun olarak zincir oluşturduğu, insanı ödüllendirme yollarının saat be saat önceden ayarlandığı, "çevre"nin bir bütün oluşturduğu, bütünüyle iklimlendirildiği, düzenlendiği, kültürelleştirildiği noktadayız. Tüketim fenomenolojisinde yaşamın, malların, nesnelerin, hizmetlerin, toplumsal davranış ve ilişkilerin bu genel iklimlendirilmesi, saf ve basit bolluktan başlayıp eklemlenmiş nesne ağlarından geçerek davranışların ve zamanın bütünüyle düzenlenmesine, drugstore'ların, Parly 2'lerin ya da modern havalimanlarının temsil ettiği geleceğin kentlerine sistemli olarak kaydolmuş ambiyans ağına kadar uzanan bir evrimdeki eksiksiz, "tamamlanmış" aşamayı temsil eder.

Günümüzde eğitim hem bir yer edinmek için gerekli ve zorunlu bir ihtiyaç haline gelmiş hem de yapay zekâ, robotlar, internet gibi birçok teknolojinin yaşamımıza girmesi ve kararları alma sorumluluğunda az sayıdaki çok işlevli teknokrat kadrosunun bulunmasının sitemin sürekliliği açısından yeterli olması nedeniyle eğitim gereksiz bir uğraş durumuna düşmüştür. Başka bir deyişle mevcut sistemin bu kadar fazla sayıda insanın bu denli eğitimine intiyacı yoktur. Denilebilirse artık eğitim oyunu oynanmaktadır. Bu oyunun içerisinde, uzatılmış eğitim süreleri, uzunca bir yaşa kadar desteklenen öğrenim, meslek içi eğitimler, yeni mesleki alanlara yönlendirme, çift diploma gibi toplumsal üretkenliği çeşitlendirmeye yönelik bir sürü şey almıştır. Küçük bir mutlu teknokrat kadrosu dışındakiler kendi kaderine terk edilmiş, toplumsal anlamda sorumlulukları bulunmayan, eğitimsel anlamda oyunlar oynayan ve iletişim araçlarıyla oyalanmaya çalışılan kitlelerdir. Sistemin utkusu artık üretken olan insanlar değil sistemin istediği rolleri oynayacak olan kitlelerin varlı̆̆ıdır ve eğitim de bu uyumun sağlanmasında pekiştirici bir role sahiptir (Çimen, 2018: 217-218). Bu bağlamda artık eğitim öğrenme amaçlı veya gelişme amaçlı bir şey değil tam tersine tüketilme amaçlı bir etkinlik olarak karşımıza çıkmaktadır. Baudrillard (2013: 44) bu duruma ilişkin şunları vurgular:

Tüketim toplumu var olmak için nesnelerine ihtiyaç duyar, daha doğrusu onları yok etmeye ihtiyaç duyar. Nesnelerin "kullanım" I sadece nesnelerin yavaş yavaş kaybolmasına götürür. Nesnelerin şiddetle yitirilmesinde yaratılan değer çok daha yoğundur. Bu yüzden yok etme, üretime temel alternatif olarak kalır: Tüketim sadece üretimle yok etme arasındaki aracı bir terimdir. Tüketimde, kendisini yok etmede aşmaya, dönüştürmeye yönelik derin bir eğilim vardır. Işte burası tüketimin anlamını kazandığı yerdir. Mevcut gündeliklilikte tüketim çoğu zaman yönlendirilen tüketimcilik olarak üretkenlik düzenine bağımlı olmaya devam eder. Bundan dolayı nesneler çoğu zaman gıyaben üretimcilik düzeninde yer alırlar ve bu nedenle bollukları bile çelişkili olarak kıtlığı simgeler. Stok, yokluğun gereksiz yinelemesi ve kaygının göstergesidir. Nesneler sadece yok etmede gereğinden fazla olarak vardırlar ve yok oluşlarında zenginliğe tanıklık ederler. Her durumda yok etme ister şiddetli ve simgesel bicimi altında (happening, potlatch, bireysel ya da kolektif yok edici eylem) olsun, isterse de sistematik ve kurumsal yok edicilik bicimi altında olsun sanayi-sonrası toplumun başat işlevlerinden biri olmaya yazgılıdır.

Eğitimle beraber simülasyon çağında ortaya çıkan diğer bir sorun ise şeffaflaşmadır. Bu durumu Baudrillard, (2001: 129-130) şu şekilde ifade etmiştir.

Video, etkileşimli ekran, mültimedya, internet, sanal gerçeklik: karşılıklı etkileşim bizi her yandan tehdit ediyor. Her yerde mesafeler birbirine karışıyor, her yerde mesafeler ortadan kaldırılıyor: cinsiyetler arasında, zıt kutuplar arasında özneyle nesne arasında, sahneyle salon arasında, eylemin başkahramanı arasında, gerçekle gerçeğin sureti arasında bir mesafe yok artık hiçbir engelle karşılaşmadan, ekranın, sanal görüntünün içine giriyoruz. Birinin hayatına girer gibi ekranın içine giriyoruz. Kendi hayatımızı dijital bir kombinezon gibi üzerimize geçiriyoruz.

Benzer şekilde eğitim üzerinden Türkiye açısından bu durumu Topçu (2017: 38) şu şekilde açıklamıştır:

Esasen mektebe herşey girmiştir, toplum hayatında ne varsa herşey. Sinema, spor, esnaf çalışmaları, aile hevesleri, iffet düşmanlığı, parti propagandacılığı, piyasa şarkıcılığı, eğlence partileri, rozetcilik, daha neler ve neler... Okuyan nesil ise okula üstün tuttuğu her zehirli vasıtayı onun kutsal duvarlarından içeriye sokmuş ve okulun kutsallığını çiğnemiştir artık. Yarışma, boykot, anarşi, isyan, bütün bunlar yıkılan Yeniçeri ocağından çıkarak okulun kutsal sınırlarından içeriye sızmış bulunuyor. Bu nesli zehirleyen, anarşi ve asaletsizlikle birleşmiş berbat bir demokrasi ve hürriyet salgını ile insandaki hırslarla kinlerin ve menfaat emellerinin, hasetlerin ve çeşitli ahlâk sefaletlerinin yayıcısı olan gazeteler, kontrolsuz ve hasta neşriyat. Bunlar mektebin hâkimiyetini kırarak ona tahakküm edici hâle geleli millet mektebi çökmüş, yıkılmış ve bir diploma dağıtma bürosu hâlini almıştır. 
Bu bağlamda Baudrillard'ın temel fikri her şeye şeffaflık kazandırmanın bir sistemin çöküşünü beraberinde getirdiği çünkü her şeyin görünür kılınması durumunda görünecek hiçbir şeyimizin kalmadığını öğreneceğimiz anlamına gelmektedir (Çimen, 2018: 23).

Gerçekliğin hiçbir çeşidiyle ilişkisi olmayan, kendi kendinin saf simülakrı olan bilgi ise sembolik ile gerçek arasındaki bağlantının tamamen çözüldüğü ve ne elde edersek, sonsuz bir yansıma dizisine girdiği içinde gerçek olmayan görüntülerin olduğu bir eğlence mekânına dönmektedir. Buna en tipik örnek olarak sınav sistemi verilebilir. Buna göre artık matematikteki oran orantı konusu gerçek dünyada şeylerin arasındaki oran ve orantıyı çözümleyebilmek amacıyla öğrenilen bir bilgi değil belirli örüntüler içerisinde çözülmesi gereken bir sembolik problem durumunu yansıtmaktadır. Buna göre en bilinen 3-4-5 üçgeni oran orantı konusundan bağımsız geometriye ait olan bir kalıptır. Kimyada katlı oranlar kanunu veya fizikteki tork da oran orantıdan bağımsız belirli problem örüntülerinde ortaya çıkan bir ilişkidir. Bu nedenle "gerçek" oran orantı konusu ise daha çok kesirlerle ilişkili matematiğe ait bir örüntüdür. Evet, geometride de kesirleri kullanırız ama 0 3-4-5 üçgeni ve üçgenlerde benzerlik konusudur işte... Baudrillard'ın "simülasyon bir alanın kendisine gönderme yapılan bir varlığın, bir tözün simülasyonu değildir." diyerek belirttiği ve modeller yoluyla ne başlangıcı ne de gerçekliği olan bir gerçeğin (réel) yani gerçekten daha gerçek olanın (hyperréel) üretilmesi olarak tanımladığı durumda tam olarak budur (Kartal, 2013: 76).
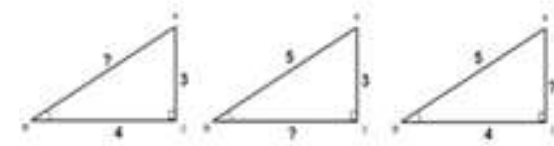

Geometriye ait örūntü alanı

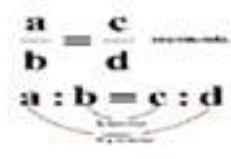

Matematige ait örüntū alan

\begin{tabular}{lll}
\hline & 6 & 2 \\
\hline$\omega$ & 1 & 1 \\
$\omega$ & 1 & 2 \\
\hline
\end{tabular}

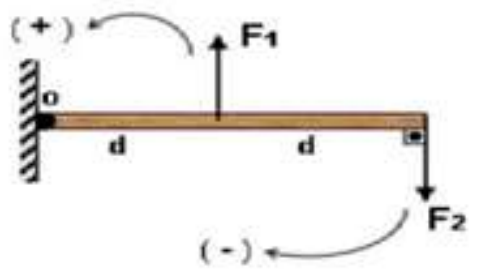

Kimyaya ait ơrūntư alanı

Fizige ait örüntü alanı

\section{Şekil 4. Dört farklı alana ait gerçeklikten kopmuş sembolik bilgi}

Bu evre sadece bilişsel anlamda değil duyuşsal anlamda da bir kopuşu içerir. Sevgi paylaşımları artık Facebook "like"larına, kızgınlık ve öfke ise trollemelere indirgenir. Anlamın aşırı hale getirilmesi, anlamın aşırı yayılması anlamın nötralize edilmesine hatta anlamın yok olmasına neden olmaktadır. Artık kendiliğinden oluşan anlam yerine medyanın yarattığı anlamlarla karşılaşmaktayız. Eğitim olaylardaki anlam ve içeriği devre dışı bırakarak bunları kendi uzay-zamanlarından bağımsız hale getirmektedir. Eğitim sisteminde öğrenilmesini beklediği anlamlar öylesine hızlı şekilde dolaşıma girmekte ve gösterilmekte, dolaşım dışına itilmekte ve yerine bir başka olay devreye girmektedir ki böylesi bir akışta anlamın yanılsanması ve imgelem mümkün olamamaktadır (Çimen, 2018: 258). Baudrillard (2011: 28) bu durumu başka bir örnek üzerinden şu şekilde ifade etmektedir:

Bunun nedeni simülasyon mantığının her şeyi egemenliği altına almış olmasıdır. Bu mantığın bir olgular ve nedenler mantığıyla hiçbir ilişkisi yoktur. Çünkü simülasyonun en belirgin özelliği en önemsiz olguları bile kapsayan gerçeğin yerini almış modellerden oluşmasıdır. Önce modeller vardır. Bir bomba gibi yörüngeye yerleştirilen bu modeller olayın gerçek çekim merkezini oluşturmaktadırlar. Bu yüzden olguların kendilerine özgü bir rotaları yoktur. Modeller aracılığıyla olgulara ulaşılmaktadır. Tek bir olgunun tüm modellere ait olabilmesi mümkündür. Bu önceden belirlenmişlik, bu daha doğmadan önce ad koyma işlemi, bu kısa devre yaptırma eylemi, modelle olgunun birbirlerine karıştırılması (olguyla model arasında anlamsal bir fark yoktur. Negatif bir elektrik akımı da yoktur. İçin için kaynayan zıt kutuplar) vardır. Modelle olgunun birbirlerine karıştırılması her defasında çelişkili olanlar da dahil olmak üzere bin bir türlü yorumun yapılmasına neden olmaktadır. Genelleştirilmiş bir süreçten yola çıkılarak modeller gibi, değiş tokuş edilebildikleri ölçüde bir gerçekliğe kavuşabilen olgularla ilgili bu yorumların hepsi geçerlidir.

Bu bağlamda her yeni görüntü bir önceki görüntüyü anlam ve gösteri olarak yok etmekte ve onun yerine geçmektedir. Dolayısıyla ekran izleyicisinin düşünmeye fırsatı olamamaktadır. Her görüntü bir önceki görüntünün katilidir (Çimen, 2018: 259). Bunu öğrencilerin çözmek istedikleri sorunun bir önceki sorunun katili olduğu sorunun anlamından ziyade temsil ettiği çözülmesi gereken şeyliği olarak ifade edebiliriz. Bu eğitimsel anlamda bir problemin keşfedilmesinin veya yeniden üretilmesinin dışlanması ve sadece istenen seçeneğin bulunacağı bir mekanizma olarak ele alındığı anlamına gelir.

\section{Baudrillard'ın Görüşleri Açısından Türkiye'deki Eğitim Programlarının Yorumlanması}

Baudrillard açısından simülasyon, "bir köken ya da gerçeklikten yoksun gerçeğin modeller aracılığıyla türetildiği "hipergerçeklik"e karşılık gelir. Simülasyon, gerçekliğe kısa devre yaptırarak onu göstergeler aracılığıyla yeniden üretir (Dikmen, 2016: 10). Baudrillard, bir işaretin veya imgenin herhangi bir gerçeklikle hiçbir ilişkisinin olmadığı, ancak "kendi saf simülasyondur" şeklindeki benzetim aşaması olarak hiper-gerçekliği sunar. Gerçek, sembolik süreçlerin operasyonel bir etkisi olarak karşımıza çıkmaktadır. Baudrillard’a göre, “işaretler gerçeklere karşı değil, birbirlerine karşı değişiyor”. Bu nedenle üretim artık başka 
işaretler üreten işaretler anlamına gelmektedir. Hiper-gerçeklik ise, her zaman zaten yeniden üretilendir (Dursun, 2018: 30). Bu doğrultuda hipergerçeklik, gerçek ve gerçek olmayan arasındaki ayrımların bulanıklaşmasına işaret eder. Bu noktada 'hiper' ifadesi, gerçeğin bir model uyarınca üretilmesi ile gerçekten daha gerçek olduğunu ifade eder (Okuyan, 2018: 71). Öyleyse, gerçeklik yalnızca simüle edilmez, ilerletilebilir de (Irwin, 2011: 389). Bu bağlamda, bu üretim sadece medya veya televizyonlar aracılığıyla yapılmaz. Bu üretimin inşasında eğitim programları da önemli bir rol oynar.

Her ne kadar eğitim programlarının ihtiyaç analizine göre yapıldığı söylemi ön planda olsa da bu ihtiyaçlar belirlenirken ne kadar objektif olunduğu ve bu ihtiyaçların belirlenmesindeki ölçme araçları ve soruların kimin oluşturduğu da en az simülasyon haline gelmiş eğitimin kendisi kadar etkili olmaktadır. En temel problem ise ihtiyacın tanımında ortaya çıkmaktadır. Baudrillard (2013: 44) bu duruma ilişkin şunları vurgular:

"ihtiyaçlar" kavramı eşitliğin gizemli sisteminde refah kavramıyla dayanışma içindedir: ihtiyaçlar güven veren bir erekler evrenini betimler ve bu doğacı antropoloji, evrensel bir eşitlik teminatına temel oluşturur. Örtük tez şudur: Tüm insanlar ihtiyaç ve tatmin ilkesi önünde eşittir, çünkü tüm insanlar nesnelerin ve malların kullanım değeri önünde eşittir (halbuki değişim değeri önünde eşitliksiz ve bölünmüştürler). Ihtiyaç kullanım değerine endeksli olduğu için, ortada bir nesnel faydalılık ya da doğal ereksellik ilkesi vardır ve bu ilkenin önün de toplumsal ya da tarihsel eşitsizlik yoktur. Biftek (kullanım değeri) söz konusu olduğunda proleter ya da ayrıcalıklı diye bir şey yoktur.

Eğitim programlarının daha çok toplumun ihtiyaçlarından ziyade belirli toplumsal grupların ihtiyaçlarına göre tasarlanmış olduğu bu noktada göz önüne alınmalıdır. Böylece bir eğitim programı hedeflenen sistemin ihtiyaç duyduğu ideal insan tipini çeşitli gösterge, imaj ve modeller durmaksızın cazibe merkezi haline getirmekte; simülasyon mantığının gerektirdiği dünyanın oluşması amaçlanmakta ve sistemin devamlılığının sağlanması sağlamaktadır. Böylece artık “ihtiyaçlar artık nesnelerden çok değerleri hedef alır ve ihtiyaçların tatmini öncelikle bu değerlerin benimsenmesi anlamına gelir. Tüketicinin bilinçdışı, otomatik temel tercihi tikel bir toplumun yaşam tarzını benimsemektir" (Baudrillard, 2013: 73).

Eğitim programlarının hedefler ögesi açısından incelendiğinde, eğitim programlarının tasarlanıyor olması da sürecin bir simülasyona bürünmesine katkıda bulunur çünkü informel öğrenmede ve insanın doğal koşullarda öğrenmesinde olayların kendiliği içinde kendi mantığında gerçekleşmesi belirleyiciyken program geliştirme ve uygulama sürecinde olay mantığında gerçekleşmesi tasarlanan şey belirleyici olmaktadır (Çimen, 2018: 261). Tasarlanan kavram ve olguların, olayların gerçekliğinin önüne geçmesi eğitim programını bir simülasyon haline getirmektedir çünkü ne kadar yakın tarihte yapılırsa yapılsın hele de günümüz dünyasında bilgi ve teknolojinin hızı programın güncelliğini zaman gerisinde bırakmaktadır. Ayrıca, belirli bir grubun ihtiyaçları ön plana çıkarılarak veya normal dağılıma göre oluşturulan genel bir program bireysel farklılıkların ihmal eden bir simüle gerçeklik olarak ortaya çıkmaktadır. Doğuştan gelen biyolojik farklılıklar, kültürel farklılıklar ve düşünsel farklılıklar muazzam boyutta elemine edilmekte ve eğitim, medya, enformasyon sistemleri nedeniyle bireyler birbirlerine tıpa tıp benzeyen kopyaların eğitilmesi amaçlanmaktadır. Yaşanan bu sosyolojik klonlama neticesinde her şeyin kopyalanması mantığı egemen kılındıktan sonra genetik klonlama ve genom projeleri işin sadece görünen kısmı olarak ortaya çıkmaktadır (Çimen, 2018: 40-41). Daha vahim olanın bu klonlamaya karşı çıkan isyankâr bireylerinde kendilerini temelsiz birtakım simulakrlar üzerinden klonluyor olmasıdır. Yakın zamanlarda ortaya çıkan punkçu, hippi, apaçi tipler bunların birer örneğidir (Baudrillard, 2013: 214-216). Bu aslında (Baudrillard, 2013: 161) özgürleşme konusunda vurguladığı durumu yansıtır:

Binlerce yıllık kölelikten ve unutulmuşluktan sonra su yüzüne çıkmaları aslında en devrimci potansiyelliği ve böylece de hangisi olursa olsun yerleşik bir düzen için en temel tehlikeyi oluşturan kadınlar, gençler, beden "özgürleşme söylemi" olarak bütünleştirilir ve yeniden ele geçirilir. Tüketmek üzere kadınlara Kadın, gençlere Gençler verilir ve bu biçimsel ve narsisik özgürleşmede gerçek özgürleşme başarıyla önlenir. Ya da: Gençler başkaldırmaya çağrılarak (Gençler=başkaldırı" ) bir taşla iki kuş vurulur: Tüm topluma yayılmış başkaldırı özel bir kategoriye sokularak önlenir ve bu kategori özel bir rolle sınırlandırılarak etkisiz hale getirilir: başkaldırı. Kadın konusunda da ortaya çıkan hayranlık verici yönlendirilmiş "özgürleşme" kısırdöngüsü: Kadınla cinsel özgürleşme karıştırılarak, kadın cinsel özgürleşmeyle, cinsel özgürleşme kadınla etkisiz hale getirilir. Cinsel özgürleşmeyle kadın, kadınla cinsel özgürleşme "tüketilir. Bu bir sözcük oyunu değil. Tüketimin temel mekanizmalarından biri, biçimsel gösterge ya da rol sistemlerinin özerkleştirilmesinden yola çıkarak ve bu sayede grup, sınıf ve kastların (ve bireyin) bu özerkleştirilmesidir.

Sistem kendisine isyan edenin bile simulakrını çeşitli filmler ve modeller aracılığıyla vermektedir. Buna göre isyankar ve marjinal olma okulu kırma, dövme yaptırma, küfürlü konuşma ve boş vermişlik olarak modellenmektedir. Bu bağlamda Baudrillard toplumsalın bittiğini, toplumsalın anonimleştiğini, toplumsalın kitleler olduğunu, politikanın çöktüğünü vurgular ve toplumsal denen şeyin buharlaştığını ve yerini kitlelerin aldığını -ki bu toplumsalın simülasyonudur- belirtir (Kartal, 2013: 59). Yokluğa gönderme yapan simülasyon, evrenle birlikte bütün bu kültürlere ait gerçeklik kavramını sorgulamamızı sağlamaktadır. Bu durum bize, gerçeğin ortadan kalktığı ve onun yerini simulakrların aldığı bir sürece götürmektedir. Bu sayede gerçeğin yeniden üretimi yaşanmaktadır (Kartal, 2013: 80).

Eğitim programlarının içeriği açısından bilginin bir simulakr haline geldiği bu noktada söylenebilir. Hatırlanacağı üzere bir simülasyon bir köken ya da gerçeklikten yoksun olan, gerçeğin modeller aracılığıyla türetilmesine, gerçekten ve fiili olarak var olan bir şeyi veya durumu bütün bileşenleriyle birlikte gerçekmiş ve fiilen varmış gibi gösterme durumu olarak tanımlanmıştır (Dikmen, 2016: 74). Eğitim sürecinde eğitim programlarının bir simülasyonun çekirdeği olmasının bir diğer nedeni de budur çünkü günümüz Türkiye'sindeki eğitim sürecinde öğrenciler fizikte tork veya kuvvet kavramını somut olarak deneyimlemezler aksine bir resim

| Kastamonu Eğitim Dergisi, 2020, Vol. 28, No. 3| 
üzerinde bir okla onu gerçekmiş gibi düşünerek hesaplarlar. Hücre onlar için mitokondri, kloroplast, koful, lizozom, ribozom, sentrozom, endoplazmik retikulum, golgi aygıtı ve plastitler gibi organellerin birleşmesinden oluşan bir resimdir veya en fazla birkaç sefer mikroskoptan baktıkları ufacık bir görüntüdür. Kimyasal reaksiyonlar çeşitli rekasiyonların toplam ve çıkarılmasını, enerji kaybı veya alımını içeren oklarla gösterilen bir yığın denklemdir. Tarihsel olaylar belirli nedenselliğin, bağlamın olmadığı bir an parlayıp kaybolan görüntülerdir. Bu bağlamda Baudrillard (2011: 11)'in "gizlemek (dissimuler), sahip olunan şeye sahip değilmiş gibi yapmak; simüle etmek ise sahip olunmayan şeye sahipmiş gibi yapmaktır." şeklinde simülasyon açıklamasına geri dönersek artık eğitimde kuvvet gündelik hayatımızda bir eşyayı kaldırırken karılaştığımız bir olgu olmaktan çıkmış, kimya çaya şeker attığımızda gözlemlediğimiz olgu yerine ondan bağımsız bir formülasyon haline gelmiştir. Simüle edilmiş bu olgular gerçeğin ne olduğunu da unutturmaktadır. Örneğin bir pamukla bir demir gibi bütün cisimlerin yerçekimin sabit olduğu sürtünmesiz bir ortamda ve diğer etkilerin ihmal edildiği durumda düştüğü ilkesi sürtünmenin ve diğer etkenlerin etkisini olduğu gerçek koşulların yerini almakta ve gerçeği bu şekilde vermektedir. Böylece, örneğin farklı kütlelere aynı kuvvetin uygulandığı durumların incelenmesi gibi kontrollü gerçek durumlarda aşılmış (örneğin böyle bir kontrollü deney sırasında bile sürtünmenin, kullanılan ipin ve cisimlerin çeşitli özelliklerinin bile göz önüne alınması gerekir) tamamen soyut ama gerçekten daha gerçek bir formül üzerinden sınavlarda sınanmak bu simülasyonun bir göstergesi olmuştur.

\section{IHTIYAÇLAR}

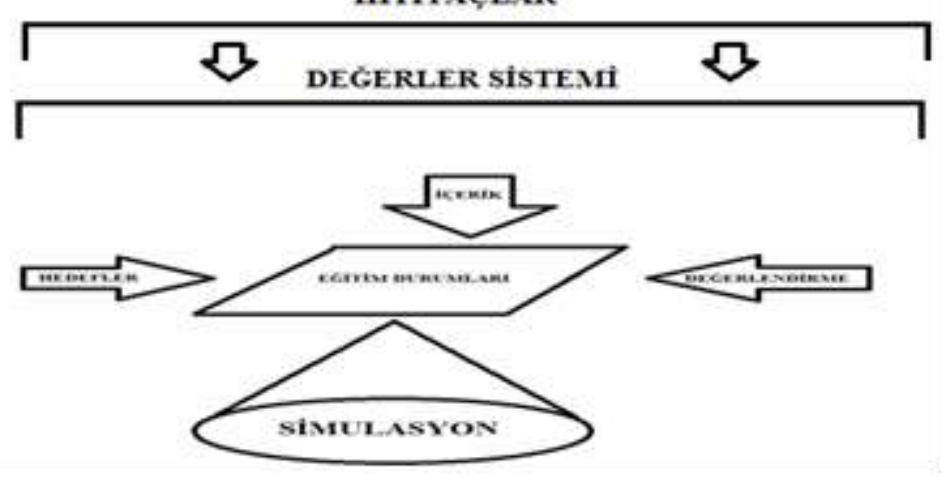

\section{Şekil 5. Eğitim programları bir simülasyon yaratmaktadır}

Eğitimle programlarının eğitim durumları açısından eğitim simülasyonundaki temel sorunun öğreten-öğrenen arasındaki ayrımın ortadan kalkması ve iletişimin sanallaşması olduğu söylenebilir. Modern aklın iflas ettiği, yerine herkesin kendi aklını, bilgisini ve yorumunu koyduğu günümüzde Baudrillard'a göre eskiden kolektif bir denetime tabi olan gerçeklik aşamasından denetimin olmadığı, yönünü şaşırdığı, bireyi ve yorumu ön plana çıkardığı ve kutsadığı bir aşamaya geçilmiştir (Küçükalkan, 2010: 35). Baudrillard (2012: 158-159) bu durumu şu şekilde açıklamaktadır:

Kendi imgemize, kendi kimliğimize, kendi görünüşümüze (look) tutsak olduğumuzdan, kendi kaygılarımızın, arzumuzun ve acılarımızın nesnesi durumuna geldiğimizden, geriye kalan her şeye karşı duyarsızlaştık. Ve gizliden gizliye bu duyarsızlıktan ümitsizliğe düştük ve her türlü tutku, özgünlük veya yazgı biçimine kıskanç lık duymaktayız. En ufak bir tutku genel duyarsızlığa yapılmış bir hakarettir. Tutkusuyla duyarsızlığınızın, kıskançlığınızın ya da ılımlıığınızın maskesini kaldıran kişi, varlığının ya da acısının gücüyle azıcık kalmış gerçekliğinizin maskesini kaldıran kişi yok edilmelidir. Iş̧te, boyun eğdirmek ya da yok etmek için öteki yeniden canlanmış, düşman sonunda yeniden bir bedende somutlaşmıştır.

Baudrillard (2015: 46)'ın vurguladığı gibi artık üretim coşkusuyla üretim üzerine kurulan şiddet oyunları artık sona ermiştir çünkü günümüzde herkes üretmektedir. Bu üretimden eğitim de nasibini almıştır. Ortaya çıkan binlerce merdiven altı ve merdiven üstü özel okullar ve üniversiteler, herkesin bir şeyler öğrettiği video kanalları artık öğretimin de yok oluşunun ilanı olarak ortaya çıkmıştır. Dolayısıyla toplumumuza özgü üretim düzeni ve eğitim programları alanında amaçlar ve araçlar arasında akılcı bir ilişki bulunup bulunmadığının yeniden sorgulanması gerekmektedir. Çünkü tüketimin temelinde artık bireysel ihtiyaçların karşılanması değil, tüketilen nesnelerin taşıdığı gösterge/değerler aracılığıyla toplumsal statünün belirlenmesi motivasyonu vardır (Güzel, 2014: 53). İkinci olarak ise artık öğretmen-öğrenci ilişkisi veya öğrenci-öğrenci ilişkisi tamamen parçalanarak yerini sanal bir biçime bürümüştür. Buna göre artık, öğretmen bir sorunun çözümünü yapmayla görevli sanal bir ekran görüntüsü haline gelmiştir. Arkadaş ise sosyal medya paylaşımlarını beğenen yakın dosttur.

Eğitim programlarının değerlendirme boyutu açısından, önceki bölümlerde tartışıldığı gibi tıpkı simülatörün gerçekten hasta olup olmadığının anlaşılamaması gibi simülasyon haline gelmiş bir eğitim programında da gerçekten kimin başarılı kimin başarısız olduğunun anlaşılması imkânsız hale gelmiştir. Bu bağlamda belirli bir süre içerisinde soru sormanın, keşfetmenin, düşünüp taşınmanın ihmal edildiği sıkıştırılmış sınavlarda ölçülen şey tepkiselliktir. Bu aslında (Baudrillard, 2013: 116) bilgisayar konusunda bahsettiği şeydir:

Bilgisayar. Burada da aynı ilke var ve öğrenme söz konusu değil. Bir küçük bilgisayar size sorular soruyor ve her soru için 5 yanıtı bir çizelge. Doğru yanıtı seçiyorsunuz. Zaman önemli: Eğer anında yanıt vermişseniz en yüksek puanı alıyorsunuz. "Şampiyon" oluyorsunuz. Dolayısıyla bu bir düşünme zamanı değil, bir tepki zamanıdır. Aygıtın işin içine soktuğu entelektüel süreçler değil, ani tepkisel mekanizmalardır. Ne önerilen yanıtları tartmak ne de düşünüp taşınmak gerekir; doğru yanıtı görmek, foto-elektrik hücrenin optik motor şemasına göre yanıtı bir uyarım olarak 
kaydetmek gerekir. Bilmek, görmektir (bkz. diğerlen arasındaki teması koruyarak ya da keserek olumlu ve olumsuz ilişkileri seçip keşfetmeye olanak tanıyan Riesman "radar" ı). Özellikle çözümleyici düşünce söz konusu olamaz: Böyle bir düşünce, kaydedilen zamana bağlı olarak verilen en düşük puan toplamıyla cezalandırılır.

Sonuç olarak mevcut sınav sistemi belki belirli bir süre içinde hızlı koşmayı ölçebilmektedir. Fakat bu seçilenlerin iyi avcı oldukları anlamına gelmemektedir. Başka bir deyişle sınav sistemi belki tutarlılık, duyarlılık açısından güvenilir olabilir fakat nitelikli bireyleri seçme ve yönlendirme noktasında geçerli bir sınav olmadığı bu bağlamda söylenebilir. Belirli bir sürede bir kişiyi nasıl en hızı koştuğu için en iyi balıkçının, en iyi avcının, en iyi tarımcının, en iyi savaşçının o olamayacağını düşünüyorsak, benzer şekilde bir sınavda başarılı olmamanın da belirli alanlarda başarısız olunacağı anlamına gelmediğinin ciddiyetle düşünülmesi ve sistemde bunu telafi edecek mekanizmaların devreye sokulması gerekir. Bizim gibi kalabalık genç nüfusu olan ülkelerde böyle kitlesel sınavlar bir bakıma zorunluluktur. Fakat bu sınavlardan başarılı olan öğrencilerin ekonomi ve gelişmişliğimize ne kadar katma değeri olmuştur, bu sorgulanmalıdır. En başarıların kaç tanesi yurtdışına çıkıp da daha dönmemiş kaç tanesi ise nitelikli insan gücü açısından mevcut topluma katkı sağlamıştır? Bu sorgulanmalıdır. Eğer mevcut sınav sistemi ve eğitim sistemi başarılı ve zeki öğrencileri seçme konusunda bu kadar başarılı ve gerçeğe uygunsan geçtiğimiz son 40 yılda yapılan sınavlarda Türkiye'de ilk 1000 giren ve Türkiye'nin en iyi üniversitelerinde eğitim görüp hatta buraları da dereceyle bitirip yurtdışında MIT, Harvard gibi üniversitelerde başarılı olan öğrencilerden en az birkaç tanesinden Avrupa'daki muadilleri gibi başarılı ve sarsıcı bilimsel buluşlar yapmış bireyler çıkması gerekmez miydi? Burada iki durum söz konusudur. Ya bu son 40 yıldaki 40000 kişi içinde böyle kişiler var ama bizim simülasyonumuz onları popçulara, topçulara yeğliyor ya da böyle birkaç kişi bile mevcut değil en azından şu anda farkında değiliz. Böylece gerçeğin gerçekten daha gerçek göründüğü, gerçekliğin yakalanmasının ve algılanmasının çok güç olduğu, gizli ve kurnazca çekilmiş çizgilerin gerçeği ortadan kaldırdığı bir dünyada yaşamaktayız. Hiper-gerçeklik durumu gerçeği yok ettiği gibi toplumsalı da yok etmeyi başardığı gibi (Çimen, 2018: 120) eğitim sistemini de iflas noktasına getirmiştir. Baudrillard 'a göre gönderen sisteminden yoksun bulunan bir simülasyon çağında, simülasyonlar artık gerçekliğin bir yansıması değil, aksine gerçekliğin kendisidir (Güzel, 2014: 59). Bu başarının da bir simulakr olarak ortaya çıkmasına neden olmaktadır. Örneğin, belirli bir konuya odaklanarak derinlemesine çalışma becerisini mevcut eğitim simülasyonu seçebilmekte midir? Yaratıcı düşünmeyi mevcut eğitim simülasyonunda teşvik edebilmekte miyiz aynı Batı'da yaratıcı yazarlık bölümlerinde veya atölyelerinde olduğu gibi ya da yaratıcılığı iki üç boyayı birbirine karıştırıp soyut sanat üretmek mi sanmaktayız? Bu bağlamda mevcut eğitim programı başarı ve başarısızlığı örten, gerçekliğin yerine bambaşka bir gerçeklik ortaya koyan koca bir simülasyondur diyebiliriz. Baudrillard (2015)'ın simülasyon bağlamında şu sözleri konuya bu noktada ışık tutmaktadır; "Birbirimizi yanlış anlamayalım. Gerçeklik ortadan kayboldu dediğimde bununla gerçekliğin fiziki (nesnel) değil, metafizik (zihinsel) anlamda ortadan kaybolmasını kast ediyorum". Bu bağlamda Baudrillard'ın gerçeklik ve illüzyonu birbirini tamamlayan bir bütün olarak olduğuna ilişkin vurgusu göz önüne alındığında mevcut eğitim programlarının gerçekliğinin aşırı gerçekliğe dönüşmesi, her yere yayılması ile birlikte düşselliğin de yok olduğunu dolayısıyla düşselliğin yok olduğu yerde gerçekliğinde ortadan kalktığını ve yerini simülasyon evreninin aldığını söyleyebiliriz (Incedursun, 2016: 17).

\section{SONUÇLAR}

Günümüzde bireyler, bu aygıtların yarattığı evrende birer "kitle" gerçeği haline gelmiş ve televizyon, reklam, imaj ve imgeler vasıtasıyla sanal olana inandırılmış ve kendi gerçekliklerini yitirmişlerdir (Okuyan, 2018: 50). Bu gerçek eğitim sürecindeki öğrenciler içinde geçerlidir. Artık onlar birer öğrenen değil belirli sınavlarda elenerek seçilen birer istatistiksel kitledir. Günümüzde yaşadığımız simülasyon çağı eğitim ve eğitim programlarını da bu simülasyonun parçası haline getirmiştir. Eğitim programlarının hedefler ögesi açısından incelendiğinde ister sisteme dahil olsun ister sistem karşıtı olsun belirli tipolojideki bireyler eğitim simülasyonunda klonlanmaktadır. Buna göre artık bilgi bir zanaatın parçası olmaktan ziyade gerçeklikten kopuk kendisi için ve kendisine göre bir simulakr haline gelmiştir. Eğitimle programlarının eğitim durumları açısından eğitim simülasyonundaki temel sorunun öğreten-öğrenen arasındaki ayrımın ortadan kalkması ve iletişimin sanallaşması olduğu söylenebilir. Eğitim programlarının değerlendirme boyutu açısından, önceki bölümlerde tartışıldığı gibi tıpkı simülatörün gerçekten hasta olup olmadığının anlaşılamaması gibi simülasyon haline gelmiş bir eğitim programında da gerçekten kimin başarılı kimin başarısız olduğunun anlaşılması imkânsız hale gelmiştir.

\section{ÖNERILER}

Bu çalışmanın sonuçları açısından yapılabilecek öneriler şunlardır:

- Baudrillard'ın fikirleri göz önüne alındı̆ında bilginin simulakrlaşmasının nasıl olumsuz bir durumken olumlu hale getirilebileceği veya risklerin nasıl fırsata dönüştürülebileceği araştırılmalı ve incelenmelidir.

- Baudrillard'ın fikirleri bağlamında eğitim programları, örtük program yönleri de dahil incelenmeli ve teknolojinin entegrasyonu eğitimdeki basit bir içerik yenilenmesi olarak görülmemelidir.

- Objektiflik sağladığı için gerçekten başarılı olanı seçme konusunda şüpheli durumda bulunan sınavların dışında bireylerin başka şekillerde de kendilerini ortaya koyabilecekleri fırsatlar tanınmalı ve oluşturulmalıdır.

- Gelecekte yapılacak çalışmalara ilişkin öneriler ise şunlardır:

- Bu çalışma, Baudrillard'ın fikirleri açısından öğrenci, öğretmen ve akademisyenlerin görüşleri alınarak yapılabilir. 
- Bu çalışma, farklı araştırma desenlerinde örneğin görüşme yöntemi kullanılarak daha derinlemesine bir sosyolojik araştırmada uygulanabilir.

- Bu çalışma, farklı metinler ve farklı filozofların görüşleri açısından karşılaştırma yapılarak tekrar incelenebilir.

\section{KAYNAKÇA}

Adaş, M. (2018). Heidegger ve Baudrillard' da teknik ve teknoloji kavramı, Yayımlanmamış Yüksek Lisans Tezi. Hacettepe Üniversitesi Sosyal Bilimler Enstitüsü, Ankara.

Baudrillard, J. (2001). Tam Ekran, İstanbul: YKY yayınları.

Baudrillard, J. (2011). Simülakrlar ve Simülasyon, Ankara: Doğu Batı Yayınları.

Baudrillard, J. (2012). Kusursuz Cinayet, ìstanbul: Ayrıntı Yayınlar.

Baudrillard, J. (2013). Tüketim Toplumu, İstanbul: Ayrıntı Yayınları.

Baudrillard, J. (2014). Nesneler Sistemi, İstanbul: Boğaziçi Üniversitesi Yayınevi.

Baudrillard, J. (2015). Şeytana Satılan Ruh Ya Da Kötülüğün Egemenliği, Ankara: Doğu Batı Yayınları.

Carl J. (2009) Industrialization and Public Education: Social Cohesion and Social Stratification. In: Cowen R., Kazamias A.M. (eds) International Handbook of Comparative Education. Springer International Handbooks of Education, vol 22. Springer, Dordrecht

Cevizci, A. (2011). Felsefe Tarihi, İstanbul: Say Yayınları.

Çimen, Ü. (2018). Jean Baudrillard'ın iletişim kuramı, Yayımlanmamış Doktora Tezi. Atatürk Üniversitesi Sosyal Bilimler Enstitüsü, Erzurum.

Dağ, A. (2009). Jean Baudrillard'da simülasyon kavramını temellendirme çabası, Yayımlanmamış Yüksek Lisans Tezi. Marmara Üniversitesi Sosyal Bilimler Enstitüsü, İstanbul.

Dikmen, M. (2016). Jean Baudrillard ve postmodernizm, Yayımlanmamış Yüksek Lisans Tezi. Uludağ Üniversitesi Sosyal Bilimler Enstitüsü, Bursa.

Dursun, A. (2018). Jean Baudrillard bağlamında modern zamanlarda varlık ve özgürlük, Yayımlanmamış Yüksek Lisans Tezi. Kırıkkale Üniversitesi Sosyal Bilimler Enstitüsü, Kırıkkale.

Ekiz, D. (2009). Bilimsel Araştırma Yöntemleri, Ankara: Anı Yayıncılık.

Güzel, M. (2015). Gerçeklik Ilkesinin Yitimi: Baudrillard'ın Simülasyon Teorisinin Temel Kavramları, FLSF (Felsefe ve Sosyal Bilimler Dergisi), sayı: 19 , s. $65-84$

Güzel, M. (2014). Postmodern dönemde epistemolojik hakikat sorunu: Baudrillard örneği, Yayımlanmamış Yüksek Lisans Tezi. Uludağ Üniversitesi Sosyal Bilimler Enstitüsü, Bursa.

Irwin, W. (2011). Matrix ve Felsefe, İstanbul: Olimpos Yayınları.

Incedursun, K. (2016). Jean Baudrillard'ın simülasyon kuramı çerçevesinde 1990 sonrası Almanya ve Avusturya sinemalarına genel bir bakış, Yayımlanmamış Yüksek Lisans Tezi. Dokuz Eylül Üniversitesi Güzel Sanatlar Enstitüsü, İzmir.

Kara, E. (2019). An analysis of Julian Barnes' England, England \& Kazuo Ishiguro's never let me go in the light of Jean Baudrillard's Simulacra and Simulation, Yayımlanmamış Yüksek Lisans Tezi. Orta Doğu Teknik Üniversitesi Sosyal Bilimler Enstitüsü, Ankara.

Karasar, N. (2008). Bilimsel araştırma yöntemi. Ankara: Nobel Yayınları.

Kartal, H. B. (2013). Jean Baudrillard'ın simülasyon teoreminin çağdaş mimarlık örneklerinde incelenmesi, Yayımlanmamış Yüksek Lisans Tezi. Yıldız Teknik Üniversitesi Fen Bilimleri Enstitüsü, İstanbul.

Küçükalkan, Y. (2010). Platon ve Baudrillard'da gerçeklik sorununun medya bağlamında değerlendirilmesi: Truman Show filmi örneği, Yayımlanmamış Yüksek Lisans Tezi. Atatürk Üniversitesi Sosyal Bilimler Enstitüsü, Erzurum.

Mendoza, Daryl Y. (2010) Commodity, Sign, and Spectacle: Retracing Baudrillard's Hyperreality. Kritike 4.2, 45-59.

Nietzsche, F. (2010). Böyle Buyurdu Zerdüşt-Herkes ve Hiç Kimse İ̧̧in Bir Kitap, İstanbul: Say Yayınları.

Okuyan, H. (2018). Jean Baudrillard'ın simülasyon kuramının temellendirildiği argümanların değerlendirilmesi, Yayımlanmamış Yüksek Lisans Tezi. Yıldız Teknik Üniversitesi Fen Bilimleri Enstitüsü, İstanbul.

Sarıca, Ö. (2018). Jean Baudrillard ve bir simulacrum olarak "Arap Baharı", Yayımlanmamış Yüksek Lisans Tezi. Çankaya Üniversitesi Sosyal Bilimler Enstitüsü, Ankara.

Sizek, S. (2012). Hiçten $A z$, İstanbul: Ecore Yayıncılık.

Topçu, N. (2017). Türkiye'nin Maarif Davası, İstanbul: Dergah Yayınları. 